\title{
The Antarctic-Magellan connection: macrobenthos ecology on the shelf and upper slope, a progress report*
}

\author{
WOLF E. ARNTZ ${ }^{1}$, SVEN THATJE ${ }^{1,4}$, DIETER GERDES ${ }^{1}$, JOSEP-MARIA GILI ${ }^{2}$, \\ JULIAN GUTT ${ }^{1}$, UTE JACOB ${ }^{1}$, AMÉRICO MONTIEL ${ }^{3}$, COVADONGA OREJAS ${ }^{2}$ \\ and NÚRIA TEIXIDÓ 2,5
}

\author{
${ }^{1}$ Alfred Wegener Institute for Polar and Marine Research, Bremerhaven, Germany. E-mail: warntz@awi-bremerhaven.de \\ ${ }^{2}$ Instituto de Ciencias del Mar (CSIC), Barcelona, Spain. \\ ${ }^{3}$ Instituto de la Patagonia, Universidad de Magallanes, Punta Arenas, Chile. \\ ${ }^{4}$ Present address: National Oceanography Centre, Southampton, UK. \\ ${ }^{5}$ Present address: Station Marine d'Endoume, Marseille, France.
}

\begin{abstract}
SUMMARY: Ecological work carried out on the Antarctic and Magellan shelves since the first IBMANT conference held at the UMAG, Punta Arenas in 1997 is summarized to identify areas where progress has been made and others, where important gaps have remained in understanding past and present interaction between the Antarctic and the southern tip of South America. This information is complementary to a review on shallow-water work along the Scotia Arc (Barnes, 2005) and recent work done in the deep sea (Brandt and Hilbig, 2004). While principally referring to shipboard work in deeper water, above all during the recent international EASIZ and LAMPOS campaigns, relevant work from shore stations is also included. Six years after the first IBMANT symposium, significant progress has been made along the latitudinal gradient from the Magellan region to the high Antarctic in the fields of biodiversity, biogeography and community structure, life strategies and adaptations, the role of disturbance and its significance for biodiversity, and trophic coupling of the benthic realm with the water column and sea ice. A better understanding has developed of the role of evolutionary and ecological factors in shaping past and present-day environmental conditions, species composition and distribution, and ecosystem functioning. Furthermore, the science community engaged in unravelling Antarctic-Magellan interactions has advanced in methodological aspects such as new analytical approaches for comparing biodiversity derived from visual methods, growth and age determination, trophic modelling using stable isotope ratios, and molecular approaches for taxonomic and phylogenetic purposes. At the same time, much effort has been invested to complement the species inventory of the two adjacent regions. However, much work remains to be done to fill the numerous gaps. Some perspectives are outlined in this review, and suggestions are made where particular emphasis should be placed in future work, much of which will be developed in the frame of SCAR's EBA (Evolution and Biodiversity in the Antarctic) programme.
\end{abstract}

Keywords: macrobenthos, Antarctic, Magellan region, biodiversity, biogeography, ecology, evolution, disturbance.

RESUMEN: LA CONEXIÓN ANTÁRTICO-MAGALLÁNICA: ECOLOGÍA DEL MACROBENTOS EN LA PLATAFORMA Y TALUD SUPERIOR, UN INFORME SOBRE LA LABOR REALIZADA. - Las investigaciones ecológicas llevadas a cabo en la plataforma antártica y de Magallanes, desde la primera reunión del IBMANT en Punta Arenas en el año 1997, se resumen en este trabajo, con el fin de identificar las áreas en que se han realizado progresos considerables, así como aquellas en las que aún quedan muchos aspectos por cubrir para poder comprender tanto el pasado como el presente de las interacciones entre las áreas antárticas y el "Cono Sur" de Sudamérica. La información que aquí se ofrece complementa la revisión de los trabajos realizados en aguas someras a lo largo del Arco de Scotia (Barnes, 2005) así como los trabajos más recientes ejecutados en el mar profundo (Brandt and Hilbig, 2004). Si bien esta revisión que aquí presentamos se centra principalmente en trabajos realizados a bordo de buques oceanográficos y en aguas profundas, se presentan también las investigaciones más relevantes hechas en las bases de tierra. Seis años después del primer congreso IBMANT son numerosos los progresos realizados a lo largo del gradiente 
latitudinal desde la región de Magallanes hasta las zonas de la Alta Antártida en los campos de biodiversidad, biogeografía, estructura de comunidades, estrategias de vida y adaptaciones, papel de las perturbaciones y su significado para la biodiversidad así como en los aspectos referentes al acoplamiento trófico entre el sistema bentónico, la columna de agua y el hielo marino. Se ha perfeccionado nuestro conocimiento del papel de los factores evolutivos y ecológicos para las condiciones ambientales pasadas y presentes, así como para la composición y distribución de especies y funcionamiento del ecosistema. Además de los avances por parte de la comunidad científica en el conocimiento de las interacciones entre estas dos regiones geográficas, son numerosos los progresos que se han producido a nivel metodológico, como por ejemplo nuevas aproximaciones analíticas para comparar la diversidad entre zonas a partir de análisis de imágenes, determinación de crecimiento y edad, modelaje trófico empleando los valores de las proporciones de determinados isótopos estables, así como el trabajo con métodos moleculares con aplicaciones taxonómicas y filogenéticas. Paralelamente se ha realizado un gran esfuerzo en completar el inventario de especies de las dos regiones adyacentes. Sin embargo, queda todavía mucho trabajo por hacer para cubrir los vacíos aún existentes en el conocimiento de ambas regiones. En esta revisión se presentan algunas perspectivas, así como sugerencias, para el trabajo a realizar en el futuro, gran parte del cual se desarrollará en el marco del programa EBA (Evolution and Biodiversity in the Antarctic) del SCAR.

Palabras clave: macrobentos, Antártida, región magallánica, biodiversidad, biogeografía, ecología, evolución, perturbación.

\section{INTRODUCTION}

Macrobenthic research is just one major topic in the frame of the IBMANT (Biological Interactions between the Magellan Region and the Antarctic) approach, which encompasses the outcome of 40 Ma of evolution in these last fractions of the Gondwana continent (Crame, 1999). IBMANT deals with the consequences of tectonics and climate change, continental drift and glaciation, as well as with those environmental and biotic factors, which are presently structuring the biota on either side of the Drake Passage (Fig. 1). Macrobenthos is an important issue in this context, because it is a particularly rich compartment, which due to its relative site fidelity preserves many characters over longer time scales than the rapidly changing plankton. In our specific case, we are looking for the
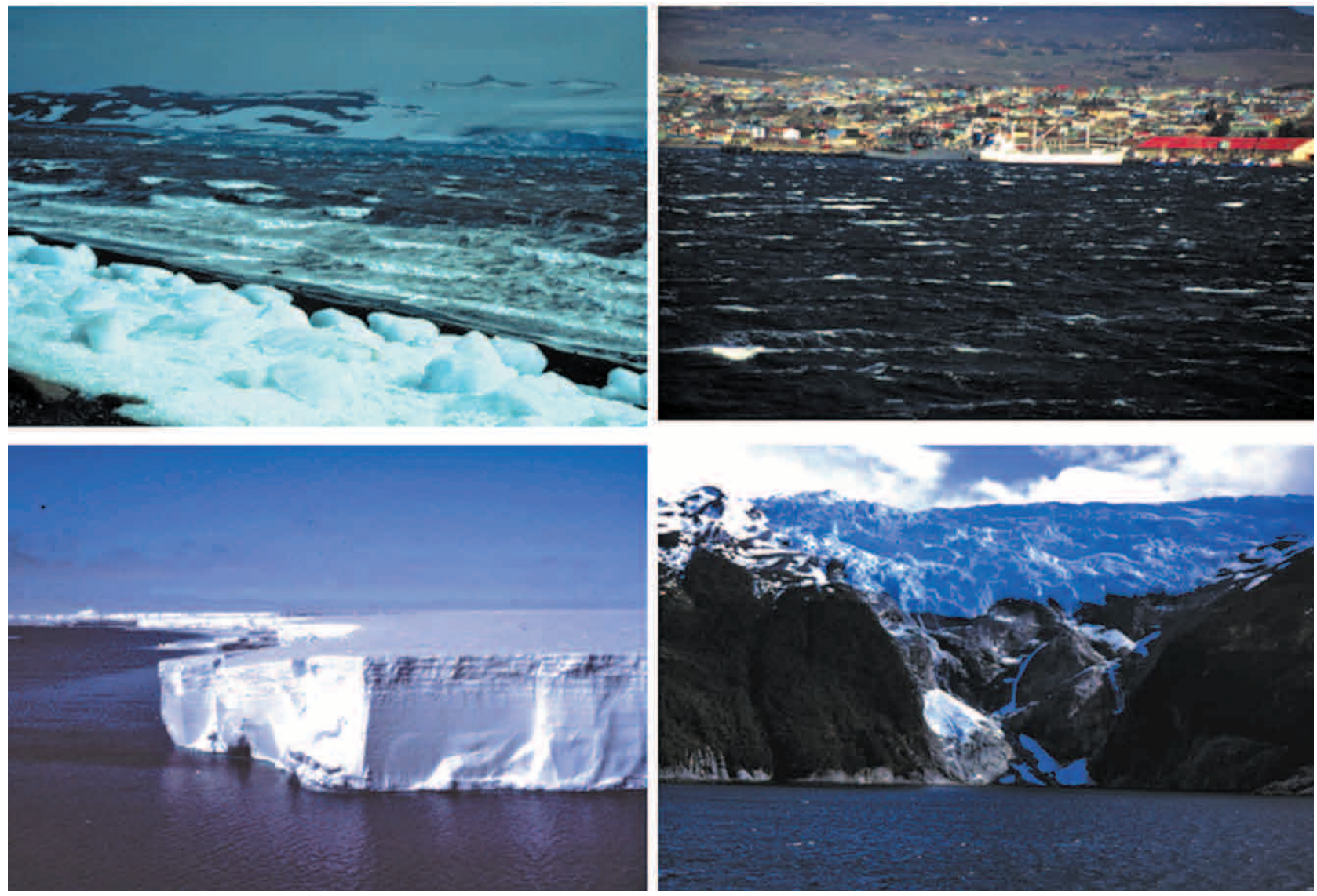

FIG. 1. - Shallow waters exposed to the effects of storm and ice are a typical aspect at King George Island (above left) whereas in the polynya facing the ice shelf margin in the Weddell Sea (below left) "shallow" bottoms begin at about 150-200 m depth. While surface waters are usually fairly calm, the seafloor is disturbed by large icebergs (see Fig. 9). In the Straits of Magellan, open shores may be exposed to heavy storms but without ice effects (above right, off Punta Arenas) whereas glaciers produce cold, low salinity waters and heavy siltation in the fjords (below right). Photos AWI; W. Arntz. 

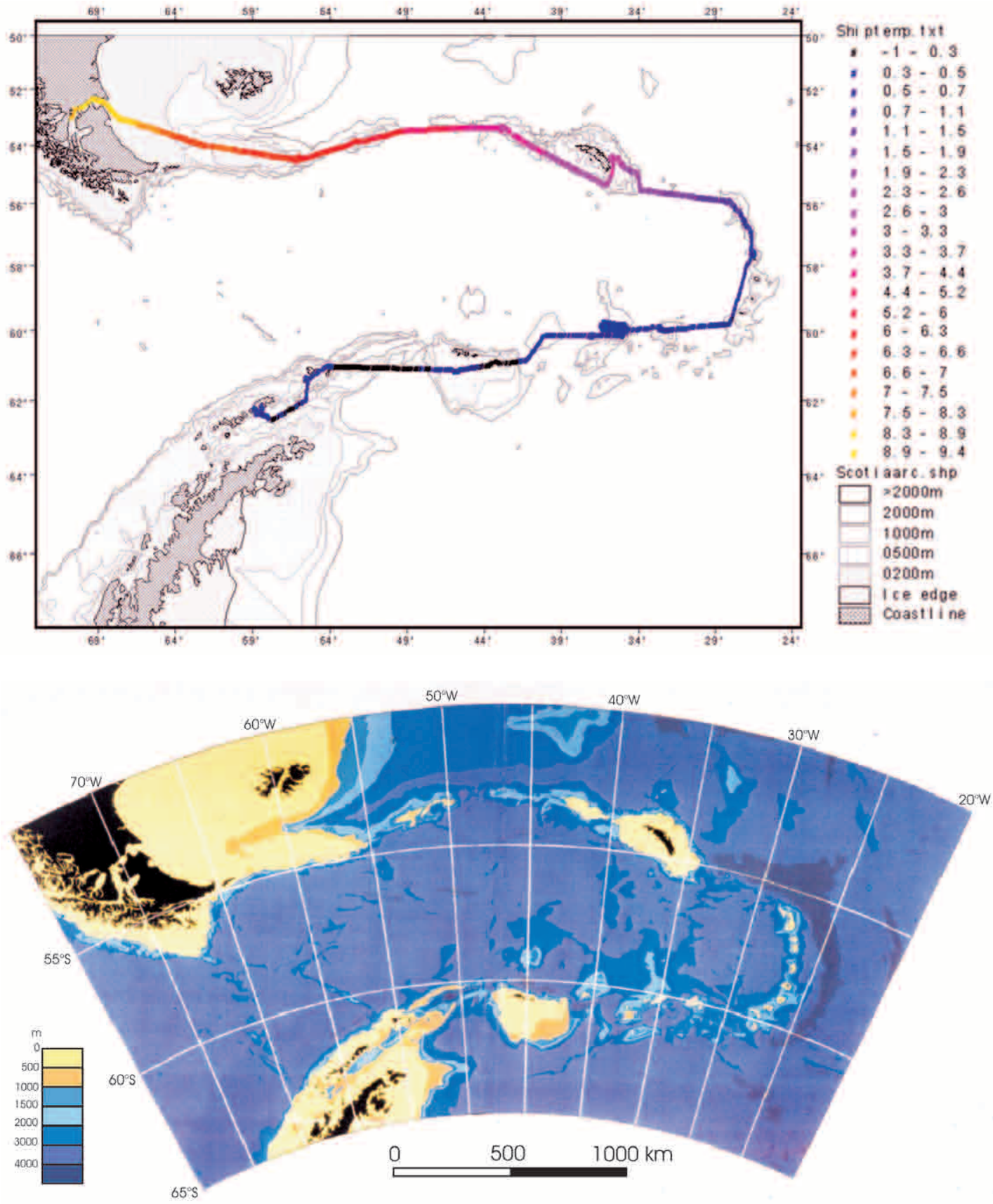

FIG. 2. - Sea surface temperatures $\left({ }^{\circ} \mathrm{C}\right)$ along the Scotia Arc during the LAMPOS cruise (ANT XIX/5) of RV "Polarstern" (April 03 to May 05, 2002). Temperatures are shown from the start of the cruise in Punta Arenas to the South Shetland Islands, revealing that the Polar Front was south of South Georgia in April 2002. (From R. Knust, unpubl.; map courtesy M. Thomson).

common heritage of those parts of the great south continent, which drifted apart while major ocean gateways opened around Antarctica, giving rise to a vigorous circumpolar current system and the Antarctic Convergence (Polar Front). Unfortunately, the exact temporal sequence of those large-scale events in the past, particularly where the Drake Passage is concerned, is not yet as clearly understood as would be desirable for the purpose of linking environmental and evolutionary processes (see
Thomson, 2005). It is very likely that major events, rather than gradual cooling over large periods, had marked effects, but we are still unable to establish a close connection between past physical events and biological processes.

A particularly interesting area for studying biogeographic and evolutionary links between the Magellan region and the Antarctic is the Scotia Arc, the only recent island and shallow-water bridge to the Antarctic, which was studied during the LAMPOS 
"Polarstern" cruise (Arntz and Brey, 2003; for nearshore research see Barnes, 2005). Cross-transport of meroplanktonic larvae (Thatje and Fuentes, 2003) through frontal zones, e.g. by eddies (Glorioso et al., 2005), might provide a connection between the northern and southern branches of the Scotia Arc, but this is more likely for deep than for surface waters (Fahrbach, pers. comm.). Clearly, W-E transport with the Westwind Drift/Antarctic Circumpolar Current (ACC), as can be seen from large amounts of drifting macroalgae (pers. obs.) and fauna rafted on algae or debris (Helmuth et al., 1994; Barnes, 2002; Thiel and Gutow, 2004; Barnes, 2005) is more likely than the reverse, or than cross-transport in this area. The situation is complicated by temperature differences between the northern and southern branch (Fig. 2). For some molluscan taxa, extremely far travel with the ACC has been registered between Patagonia and New Zealand (16,000 km; Beu et al., 1997), but even this may be easier than ,island hopping“ between the two branches of the Scotia Arc or movement against the main current direction.

This review compiles data from various cruises and some shore stations. Of course not all the information included here was created within the IBMANT frame, but the programme certainly stimulated interest in the Magellan-Antarctic connection, with a focus on work on the continental shelves. Deep-sea macrobenthos studies within the ANDEEP context, which were presented at the same Conference in Ushuaia, are published in another volume (Brandt and Hilbig, 2004). Taxonomic work is only marginally included in this review, because a full presentation would have gone far beyond its scope.

\section{RECENT PROGRESS}

\section{Links to the past}

\section{Evolutionary and ecological factors shaping present-day environmental conditions and species composition}

Much new information has been created in recent years on climate fluctuation and glaciation in Antarctica and the Southern Ocean in the past. Some of it is based on carbon and oxygen isotope records from fossil foraminifers in deep-sea sediments (Zachos et al., 2001a,b). These and other data have led to conclusions about the origin of the present Antarctic ice sheet, formation of the Antarctic Cir- cumpolar Current (ACC) and the gradual cooling of the ecosystem. There seems to be a consensus now that ice growth on East Antarctica began at least 40 Ma ago, and that the Tasman ocean gateway was essentially open by 34 Ma (Mackensen, 2004). However, while an improved scenario is developing on larger time scales, certain details of greatest interest to the biologists, such as the definite opening of the Drake Passage-a subduction zone-and the date of formation of a vigorous ACC, that seemed to be solved almost 30 years ago (Barker and Burrell, 1977) remain obscure, as has been reviewed in a recent paper (Barker and Thomas, 2004). Ocean gateways do not open overnight; the change from shallow seas connecting the former parts of Gondwana to the present deep-sea floor in the passage separating them must have been a gradual one. The Antarctic Circumpolar Current (ACC) is the mightiest current system on Earth, and to function the way it does it requires deep water without major obstacles (Barker and Thomas, 2004). Even nowadays, the relatively narrow opening of the Drake Passage creates numerous eddies as the West Wind Drift is forced through it (Glorioso et al., 2005). A simultaneous definite opening of the two large gateways on either side of the Antarctic continent about $34 \mathrm{Ma}$ ago, as is postulated by some geologists, seems unlikely from a biological point of view because of the much greater difference between the Australian and Antarctic marine fauna as compared to the relatively narrow faunistic relations between the Antarctic and South America (Arntz and Ríos, 1999). In fact, some molecular datings of major faunal changes (see below) might rather support a final separation of the Antarctic and South American continents by cold deep water at the time of midMiocene cooling (16-14 Ma) when the "tectonic reorganisation of the gateway regions may have altered poleward heat and moisture transport, resulting in Antarctic ice growth and global cooling" (Shevenell et al., 2004). At any rate, notwithstanding the existence of intermittent continental ice sheets since the E/O transition, there is a marked $\mathrm{d}^{18} \mathrm{O}$ increase in middle Miocene cores that may have resulted from an increasing ice volume and deep-water cooling (Wright et al., 1992), and which reflects one of the major steps in the process of Antarctic isolation.

In general, not one single event such as a meteorite impact seems to have shaped evolution in the Antarctic, but rather various tectonic, climatic, and oceanographic changes that influenced different 
taxa in different ways (Clarke and Johnston, 2003). Several Southern Ocean gastropod and bivalve genera can be traced back to at least the late Eocene (Crame, 1997). The origins of part of the present fauna are even with the coastal fauna of Gondwana prior to break-up, potentially going back to the Mesozoic or Palaeozoic (Aronson and Blake, 2001; Gili et al., in prep.). Are the high Antarctic threedimensional communities of sessile suspension feeders (sponges, bryozoans, anthozoans, ascidians) on high Antarctic soft bottoms a result of environmental conditions, which resemble those in Cretacean shallow epicontinental seas? For example, the lack of continental and riverine runoff from a frozen continent and the ensuing transparency of the water might favour sessile suspension feeders in a similar way. There are other similarities to palaeoconditions such as the lack of "skeleton-breaking" predators (Aronson and Blake, 2001). The fragmentation of Gondwana influenced the fauna particularly by the introduction of a Tethyan element through the Weddell Province (Clarke and Crame, 1989).

During evolution in situ, climate change and glaciation resulted in the extinction of some groups, and provided evolutionary opportunities for others. More recently, development of the fauna may have been triggered by exchange along the Scotia Arc, possibly assisted by eddies, and with the deep sea (for processes, ecological barriers and pathways involved in such exchange in the Arctic see Vermeij, 1991).

Present global warming may well provide once more a situation where exchange is enhanced. Conditions in the Potter Cove (South Shetland Is.), under heavy siltation from a melting glacier, show what the Weddell Sea shelf might look like under continued warming. However, conditions may have been less stable than supposed hitherto even during major glaciations, when the advancing ice cap pushed shelf sediments down the continental slope (Thatje et al., 2005b). Presently there is a gradient of decreasing turbidity and increasing importance of sessile soft-bottom suspension feeders from Patagonia to the high Antarctic. Exceptions, such as the highly structured gorgonian assemblages on Burdwood Bank and in some Patagonian fjords, live on hard bottoms, as do most recent sessile suspension feeders worldwide.

For the Magellan region, recent work has concentrated mainly on the development after the last ice age. Glaciation in this region never quite reached the extremes occurring on the Antarctic continent, but there still was an extensive ice cap around the
Late Glacial Maximum (LGM) about 21 ky BP (Clapperton, 1993b) and later (Clapperton et al., 1995), the remainders of which are still recognizable in the South Patagonian Icefield. The fjords and channels of Patagonia and Tierra del Fuego were covered by a thick ice cap from 35 to $55^{\circ} \mathrm{S}$ during the LGM (Clapperton et al., 1995; Benn and Clapperton, 2000). During this period the Southern Ocean suffered distinct cooling, accompanied by an expansion of Antarctic winter and summer sea ice (Gersonde et al., 2003). Northward expansions and withdrawals of the ACC seemingly were also the main reasons for millennial-scale climate variations after the LGM and during Patagonian glacial retreat until about 12 ky BP (Lamy et al., 2004). The LGM and the processes during gradual warming, which was interrupted by various glacier readvances (Clapperton, 1993a), probably shaped much of the biogeographic pattern that we find nowadays. The sea level was lower during glaciation than today, and the earliest seawater incursion into the Straits of Magellan after the retreat of the glaciers occurred only around $8 \mathrm{ky} \mathrm{BP} \mathrm{(McCulloch} \mathrm{and} \mathrm{Davies,} \mathrm{2001).}$ Since then, the ice sheet has been retreating substantially (Lamy et al., 2002), leaving as ultimate remains under global warming conditions the South Patagonian Icefield and a number of glaciers descending from the mountain chains of the Andes and the Cordillera Darwin.

During the Holocene, shifts of the latitudinal position of the Southern Westerlies became the principal climate factor in the "Cono Sur" (Lamy et al., 1999, 2001, 2002). Temperature and salinity reached maximum values shortly after the "Holocene optimum" at about 6 ky BP and then started their decline to modern values (Lamy et al., 2002). Reduced advection of cold, nutrient-rich Subantarctic water through the ACC, reduced precipitations, diminished advection of Chilean fjord water of low salinity and/or reduced supply of freshwater and micronutrients characterised the Chilean/Argentinean fjord region during the midHolocene. Continental rainfall increased again during the late Holocene, from about $4 \mathrm{ky} \mathrm{BP}$, and decreasing temperatures point to another equatorward shift of both the ACC and the Westerlies in the period until present. Recently, Rignot et al. (2003) estimated the volume change of the largest 63 glaciers in Patagonia and found an acceleration of ice loss since 1995 as compared to the preceding period. Thinning of these glaciers is faster than can be explained from warmer air temperatures and 
decreased precipitation, and their contribution to sea level rise is relatively higher than that of Alaska glaciers (Rignot et al., loc.cit.).

Recolonisation of the Beagle Channel and the Straits of Magellan, in comparison to the open oceans off Patagonia and Antarctic deep waters, occurred quite recently, as these areas became gradually icefree only during glacial retreat after the LGM.

Recent ("ecological") factors shaping the benthos have been studied for quite some time, with emphasis on the Weddell and Ross seas in the high Antarctic, the Antarctic Peninsula, the Scotia Arc and the Straits of Magellan. Trends do not always go into the same direction: While the Peninsula is experiencing a period of rapid warming by about $0.5^{\circ} \mathrm{C}$ per decade, the Ross and Weddell seas appear to be undergoing a period of cooling (Vaughan et al., 2003). Glacier retreat is reported from the western side of the Antarctic Peninsula and the Magellan region, and ice shelf retreat from the eastern side of the Antarctic Peninsula (Vaughan and Spouge, 2002). Inorganic silt of glacier origin increasingly impoverishes and alters benthic communities in such areas (Klöser et al., 1996; Mutschke et al., 1996; Thatje and Mutschke, 1999) and adds to the effect of storms, waves, ice scour by bergs and growlers, anchor ice and biotic interaction (Sahade et al., 1998; Barnes, 2005).

The combination of evolutionary and ecological factors shapes the aspect of present-day assemblages in the Southern Ocean, presumably with a certain increase in importance of evolutionary, and a decrease in importance of ecological processes towards the pole. Presently, ecological factors may be gaining importance (Poulin et al., 2002), making the Antarctic Peninsula less Antarctic and more similar to the Magellan region, but in the large-scale context of geological and climate history this represents just another oscillation.

We may have a long way to go until we can associate major extinctions, radiations etc. in the sea with specific tectonic, climatic, glaciological or oceanographic events. Hopefully, however, we may be able-in close cooperation with other disciplines - to identify some major events when several important groups were affected at the same time (see Thomson, 2005).

\section{New molecular results on radiation and extinction in the Antarctic benthos}

Some progress has been made in molecular and biochemical work on extinction and radiation of species. Antarctic decapods suffered major extinctions whereas pycnogonids, amphipods, and isopods underwent major radiations. Fish, not dealt with explicitly in this review, suffered broad extinction, and the teleost taxon Notothenioidei showed rapid active radiation within a few million years (Bargelloni et al., 2000; Eastman, 2000; Pisano and OzoufCostaz, 2000). Chen et al. (1997) put the basal notothenioid radiation at about $15 \mathrm{Ma}$, which would coincide fairly well with the mid-Miocene cooling event and presumed significant growth of the East Antarctic ice sheet (Eastman and Clarke, 1998, Clarke, 2003a).

The isopod families Antarcturidae and Serolidae (Fig. 3) are among these latter taxa (Brandt, 1991, 2000; Brandt and Poore, 2003). Held (2000) did a molecular study on 16 species of serolid isopods from Antarctic waters, the deep sea, South America and Australia. This investigation has important consequences for understanding the biogeography of the Serolidae, indicating that all Antarctic species studied form a monophyletic group, which stems from species with closest extant relatives in South America. The 3 deep-sea species included in the study are closely related to species living on the Antarctic shelf, indicating parallel colonisation of the deep sea by way of polar submergence. The radiation of the shelf serolids probably occurred after the opening of the Drake Passage and increasing isolation of the Antarctic (Held, 2000).

Speciation rate of polar taxa does not seem to be slower than in warm water taxa (Held, 2001), a suggestion made also by Clarke and Crame (1997). "This suggests that the continuous evolutionary change (....) will not be mutation-limited" (Clarke, 2003a). This seems paradox in view of the long embryonic development, slow growth, late first maturity, reduced fecundity and retarded generation time of most Antarctic invertebrates (Arntz et al., 1994).

Speciation seems to continue at a high pace nowadays. E.g., sequences from the mitochondrial $16 \mathrm{~S}$ ribosomal RNA gene show that the serolid isopod Ceratoserolis trilobitoides consists of several species (Held, 2003), as had been suspected before by Wägele (1986) because of the polymorphism in this "species". At least four species seem to form the Glyptonotus antarcticus group (Held and Wägele, 2005). There may be many more cryptic species in the Antarctic benthos, raising considerable doubts as to the generally assumed "circumantarctic" distribution of the benthos. 


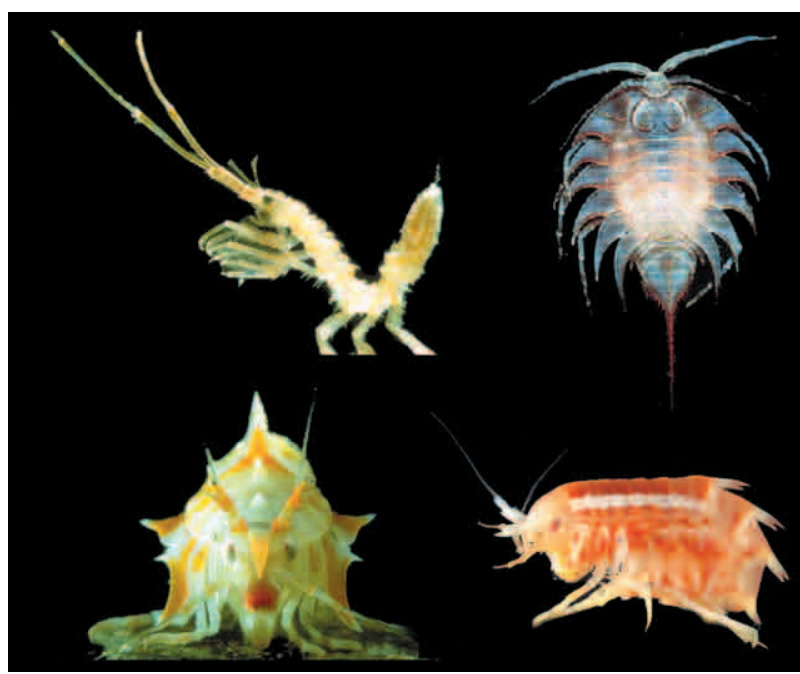

FIG. 3. - Among those peracarid crustaceans that radiated in the Miocene, Antarcturidae and Serolidae (above) are the most spectacular cases among the isopods while Epimeriidae and Iphimediidae (below) represent the amphipods. Due to their abundance and ubiquity, some species of these families are excellent candidates for checking circumantarctic distribution and cryptic speciation. (Photos: M. Klages, M. Rauschert).

Phylogenetic origins of Antarctic amphipod crustaceans are difficult to elucidate, because no fossil remains of this group have been found in the Antarctic. Lörz and Brandt (2004) studied phylogenetic relations of 14 species in the amphipod families Iphimediidae and Epimeriidae (cf. Fig. 3), both dominant taxa in the Antarctic benthos, which may result in a rearrangement, as e.g. the Eusiridae turned out to be closer to the Iphimediidae than thought hitherto. Ontogenetic characters were not helpful in revealing phylogenetic changes in two Epimeria species by Coleman (1990). So far no deep-sea material of the two amphipod families has been retrieved from the Antarctic, which might be helpful for the reconstruction of phylogenetic trees and the descendence of shallow-water forms in the high Antarctic Weddell Sea. Recent calculations arrive at a radiation date for Antarctic Epimeria species of 15.7 Ma (Lörz and Held, 2004, based on the cirripede rate of substitution). This would correspond better than previous datings with the proposed formation of the Antarctic Circumpolar Current isolating Antarctica (see above). High intraspecific variability suggests continuing speciation in the genus Epimeria.

Another molecular study dealing with the phylogeny of the common Antarctic sea urchin Sterechinus neumayeri (Lee et al., 2004) revealed close relations to the South American urchin Loxechinus albus, concluding that the two species may have diverged from the lineage of a southernmost South American sea urchin by vicariance as Antarctica and South America separated. However, the temporal range given for this process, with 24-35 Ma ago, appears rather wide to relate it to specific environmental situations.

The phylogenetic relationship between the limid bivalves Limatula ovalis, living in the high Antarctic, and L. pygmaea, from the Subantarctic and the Magellan region were studied by Page and Linse (2002). Proposed divergence of these and a third species, L. hodgsoni, was between about 1.48.0, 6.8-19.1 and 0.2-2.9 Ma, depending on the molecular clock used, i.e. probably after the final opening of the Drake Passage and the formation of the Polar Front. This might be taken as a hint that the Polar Front is not as effective a barrier as usually thought.

\section{Species distribution, zonation, biogeography and biodiversity}

\section{Completing the record}

Enhanced research on the Magellan-Antarctic gradient has considerably increased data on biogeographic distribution and taxonomy of many taxa. Notable recent examples are Antarctic macroalgae (Wiencke and Clayton, 2002) and echinoids (David et al., 2005), Magellanic shelled molluscs (Linse, 2002), opisthobranchs (Schrödl, 2003), and particularly, polychaetes (Parapar and San Martín, 1997; San Martín and Parapar, 1997; Cantone et al., 2000; Gambi et al., 2000; Montiel et al., 2004, 2005). For a taxonomic update of all benthic groups see Clarke and Johnston (2003). Further information is being compiled on, e.g. Magellanic asteroids and Antarctic cnidarians. As this recent work adds to a large extant literature, the Southern Ocean shelves are now rather among the better studied parts of the world ocean. This does not hold, however, for the deep-sea areas surrounding Antarctica (Linse, 2004).

In some cases biogeographic patterns begin to emerge for recently studied taxa, which add to the data presented at IBMANT I (Arntz and Ríos, 1999). Macroalgae show a marked reduction from the Magellan region (Santelices, 1989, Cornejo, 1996) along the Antarctic Peninsula towards the high Antarctic, whose continental shelf exhibits a very sparse macroflora (Wiencke et al., 1998; Wiencke and Clayton, 2002). There are, however, 
differences between the Ross Sea and the Weddell/Lazarev seas, where hitherto a single small piece of red alga has been found (Gambi, pers. comm.), which might be allochthonous. Polychaete similarity with the Magellan region is greater at the Antarctic Peninsula than in the Weddell Sea (Montiel et al., 2005). The same is true for isopods and cumaceans (Brandt et al., 1997, 1999). Like in other taxa, Antarctic endemism is currently reduced by new finds in adjacent areas. Tanaidaceans were subject of two recent studies in Admiralty Bay (Blazewicz and Jazdzewski, 1996) and the Beagle Channel (Schmidt and Brandt, 2001). Surprisingly, the Peninsula material showed a lower overlap (abt. $10 \%$ ) with the Weddell Sea (Sieg, 1992) than the Magellan region (25\%).

The IBMANT I compilations of decapod crustaceans in the Magellan region (Arntz et al., 1999) and their Southern Ocean distribution (Gorny, 1999) have been complemented by recent finds of lithodids in the Amundsen and Ross seas (Arana and Retamal, 1999; Thatje and Lörz, 2005) and near Bouvet Island (Arntz and Brey, 2005; Spiridonov et al., in press), of caridean shrimp along the Scotia Arc (Arntz and Brey, 2003; Romero et al., 2003a), and of thalassinids in the Beagle Channel (Thatje, 2000; Thatje and Gerdes, 2000). The general picture is still valid; only caridean shrimps have been collected on the high Antarctic shelves, and except for king crabs (Anomura: Lithodidae), no anomurans and no brachyurans live in Antarctic waters as for these latter groups, the deep water of the Drake Passage and the Polar Front are a true faunal barrier (Thatje et al., 2003, 2005a, but see Thatje and Fuentes, 2003). The Lithodidae have so far not been found on the high Antarctic shelves (Thatje and Arntz, 2004).

\section{The "bell-shaped latitudinal curve", species richness and diversity}

Latitude by itself is not an environmental factor, but it reflects to a certain degree some basic ecosystem properties such as day length, light, temperature and production. On the other hand, a comparison of the conditions along the Atlantic and Pacific coasts of America (Boschi, 2000; Gutt et al., 2003) reveals that there are other factors, which make a differentiation necessary (see also Gallardo and Penchaszadeh, 2001; Valdovinos et al., 2003). Therefore it is not surprising that the controversial issue of a bell-shaped curve (see Arntz and Gili, 2001), with

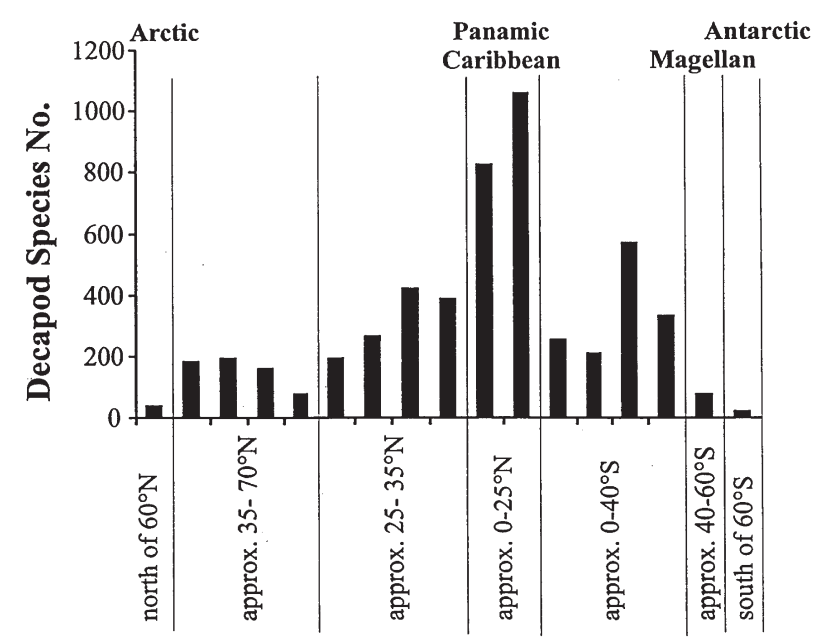

FIG. 4. - Numbers of decapod species from the Arctic to the Antarctic (data from Boschi, 2000). Note that the bars in the different latitudinal ranges do not represent consecutive latitudinal values but are from separate counts of species. This is one of the few cases where a "bell-shaped latitudinal curve" seems to exist, and in the case of decapods species numbers are indeed very low in the Antarctic.

decreasing species richness toward the pole, suggested by some authors for the terrestrial realm worldwide (see Gaston and Chown, 1999) and marine areas of the northern hemisphere (Roy et al., 2000), seems to occur only in a few taxa in the southern hemisphere, whereas in many others even an increase from the Magellan region to the Antarctic can be observed.

A clear latitudinal cline is shown by macroalgae, whose distribution is highly dependent on water depth, light and temperature. In contrast to the (partly shallow) Ross Sea, in the southern Weddell Sea the non-existence of shallow bottoms excludes macroalgae (see above). Species richness in decapod crustaceans also seems to follow a bell-shaped curve (Boschi, 2000; Dworschak, 2000; Fig. 4); however, with marked differences in the subgroups (cf. above). A bell-shaped curve may apply to some extent also to fish, which are not dealt with here.

For gastropods and bivalve molluscs there is a clear decrease in species richness from the tropics to the Antarctic, but "local hotspots" deviate from a continuous decrease (Crame, $2000 \mathrm{a}, \mathrm{b}$ ), and in the SE Pacific there is even a steep increase between $42^{\circ} \mathrm{S}$ and Cape Horn $\left(55^{\circ} \mathrm{S}\right)$ (Valdovinos et al., 2003). The number of polychaete species does not reveal a decreasing pattern along the Chilean Pacific coast (Hernández et al., 2005) nor a MagellanPeninsula-Weddell Sea gradient (Montiel, pers. comm.). Overall, latitudinal clines in species richness do not seem to be a general dominant pattern within the Antarctic due to a mostly non-meridional 
orientation of most of the shelves (except for the Peninsula) and the circumpolar currents (Clarke and Johnston, 2003). Obviously, the paradigm of a bellshaped curve in general has to be abandoned for the southern hemisphere in favour of an asymmetric distribution of most taxa (Gray, 2001; Crame, 2000a).

Considerable progress has been made in the past decade in collecting and publishing quantitative data on zoogeographical patterns. To relate these data to ecosystem functioning along a latitudinal gradient, sampling has to be standardized in time and space, analytical methods have to be comparable, and many if not all species have to be determined. Even if these conditions are fulfilled, the innate complexity of biological systems and their dynamics may complicate comparisons. The ultimate step of relating Antarctic data to those of the Magellan region has not yet been taken, although the methodological prerequisites for such a comparison are now available.

From many scattered data we know that species richness in the Antarctic can range from very high to very low; overall the species richness was found to be higher than formerly expected (Arntz et al., 1997; Clarke and Johnston, 2003), also in the deep sea (Brandt and Hilbig, 2004). In some taxa species richness has been increasing steeply in past years due to increased sampling, as has best been documented in amphipods (De Broyer et al., 2003). The most speciose groups in the Antarctic are polychaetes, gastropods, amphipods and isopods. Macroalgae, decapods, bivalves (and teleost fish and selachians) are poorly represented if compared with these taxa at lower latitudes, even in the Magellan region, whereas pycnogonids and many suspension feeding taxa are particularly species rich. Echinoderms are well established on both sides of the Drake Passage. Decapods and fish were previously well represented in Antarctic waters, but impoverished in the course of Antarctic cooling (Thatje et al., 2005a and lit. therein); other groups incl. pycnogonids, amphipods, isopods (and teleost fish) have undergone marked radiations (Lörz and Held, 2004). However, in all cases it is only some lines that have diversified (Clarke and Johnston, 2003). Poor groups can have a high share in the worldwide species (e.g., priapulids).

Species numbers per haul in bottom trawls (Table 1) or Agassiz trawls (not shown) are much higher than in temperate regions (own unpubl. data). Raw data of all species determined on EASIZ I with the help of many specialists arrived at a number of about 800 defined species. Gutt et al. (2004) made an extrapolation using species accumulation approaches (Ugland et al., 2003) and calculation of the unknown number of species, which were not represented in the samples, as a function of the rare species (Colwell, 1997), arriving at an estimate for total macrozoobenthic species between 2100 and 10,000 for the Weddell Sea shelf and between 11,000 and 17,000 for the entire Antarctic shelf. Both estimates are likely too low, because the method is conservative; trawls were used, which are known to be selective; and the assumption is that there really is a circumantarctic fauna (cf. Held, 2003; Held and Wägele, 2005), i.e. all assemblages to be found in the future would resemble those that have been described to date.

This kind of species richness extrapolation cannot be used to compare diversity, which is a function of species numbers and their numerical share. However, assuming that the reduced species numbers in the samples are representative, the calculated ,pseudodiversities" should also be representative of true diversities. Seabed photography and UW video fulfil this important criterium by focussing only on the mega-epifauna, as has been shown in a bipolar comparison (Gutt and Starmans, 2001).

The importance of considering scales in diversity studies was shown by Starmans and Gutt (2002), who used UW video to compare mega-epibenthic assemblages in the Weddell and Bellingshausen seas with Arctic assemblages (NE Greenland) in a depth range between 35 and $585 \mathrm{~m}$. At regional scale (gamma diversity) taxa richness was greater in the Antarctic than in the Arctic, although shallow sites in the Arctic were slightly richer in species and species turnover (beta diversity), indicating also higher habitat diversity. At the local scale (alpha diversity) species numbers were higher in the Antarctic. As a next step, macrobenthic diversities derived from Antarctic photographs (Gutt and Starmans, 1998) might be compared with the material taken by Gutt et al. (1999) from the Magellan region.

\section{Community structure}

Numerous soft-bottom investigations on macrobenthic communities have recently been carried out in the southern hemisphere using both visual and invasive methods at different sites in Antarctica and covering in total a wide latitudinal range (for the period before IBMANT I, see Gerdes et al., 1992 and citations therein): Saiz-Salinas et al., 1997; 
TABLE 1. - Number of invertebrate species per bottom trawl haul. A, in the Kapp Norvegia to Halley Bay area on cruise EASIZ I (ANT XIII/3). B, in the Kapp Norvegia - Austasen area on cruise EASIZ III (ANT XVII/3). Source: Sirenko et al. (1997, 2001); further details there. For exact positions, net characteristics, trawling duration, iceberg disturbance etc. see also Balguerias et al. in Arntz and Gutt (1997) and Knust et al. in Arntz and Brey (2001).

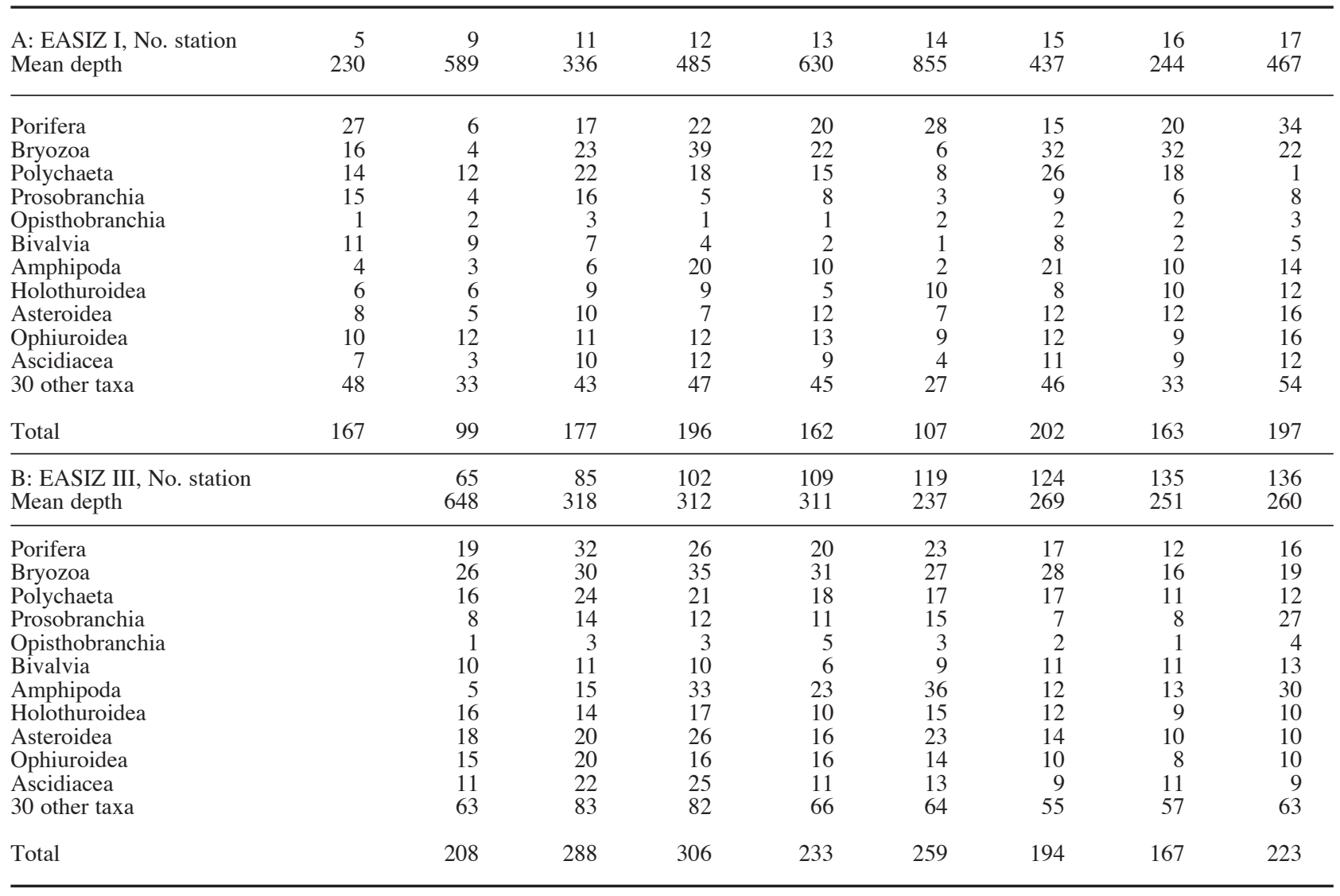

Arnaud et al., 1998; Starmans et al., 1999; Gambi and Bussotti, 1999; Ramos, 1999; Cattaneo-Vietti et al., 2000a; Gambi et al., 2000; Piepenburg et al., 2002; Cranmer et al., 2003; Lovell and Trego, 2003). However, direct comparisons across latitudes remain rare.

Using a multibox corer Gerdes et al. (1992) had presented first abundance and biomass figures from the Weddell Sea shelf and slope and reviewed the data available at that time. Piepenburg et al. (2002) compared abundances and biomasses along two shelf/slope transects in the Drake Passage and Bransfield Strait. Table 2A summarizes the results of grab and corer based studies on the high Antarctic Weddell Sea shelf and in the Peninsula area. These studies showed the macrobenthos to occur often extremely patchy at the different sites, with minimum and maximum values of abundance and biomass (sieved over $500 \mu \mathrm{m}$ ) varying between 100 to more than 47,000 ind. $\mathrm{m}^{-2}$, and 0.1 and $1673 \mathrm{~g}$ wet wt. $\mathrm{m}^{-2}$, respectively. The Lovell and Trego (2003) epi- and infauna studies with grabs at Port Foster revealed even higher abundances but compa- rable biomass, because of sieving over $300 \mu \mathrm{m}$ mesh size with groups such as foraminiferans, polychaetes, and nematodes being numerically dominant. Whereas a pronounced shelf-slope gradient in benthic abundances and biomasses was found everywhere in the Antarctic and the Magellan region, there did not seem to be any clear latitudinal trend in these parameters (Gerdes and Montiel, 1999; Piepenburg et al., 2002). Macro- and megabenthic assemblages are most likely determined by food supply (which is depth-dependent), but apparently respond differently to secondary driving forces such as, e.g. seabed topography.

Locally biomasses can be extremely high, not only in the high Antarctic sponge dominated suspension feeder communities (Gili et al., 2001; Gerdes et al., 2003), but everywhere. The bivalve Laternula elliptica reaches biomasses of up to $5 \mathrm{~kg}$ wet wt. $\mathrm{m}^{-2}$ in the Potter Cove (Mercuri et al., 1998), which is comparable to very productive upwelling beaches off Peru and Chile (Arntz et al., 1987). Different species of scallops contribute to high benthic biomasses both in the Straits of Magellan and the 


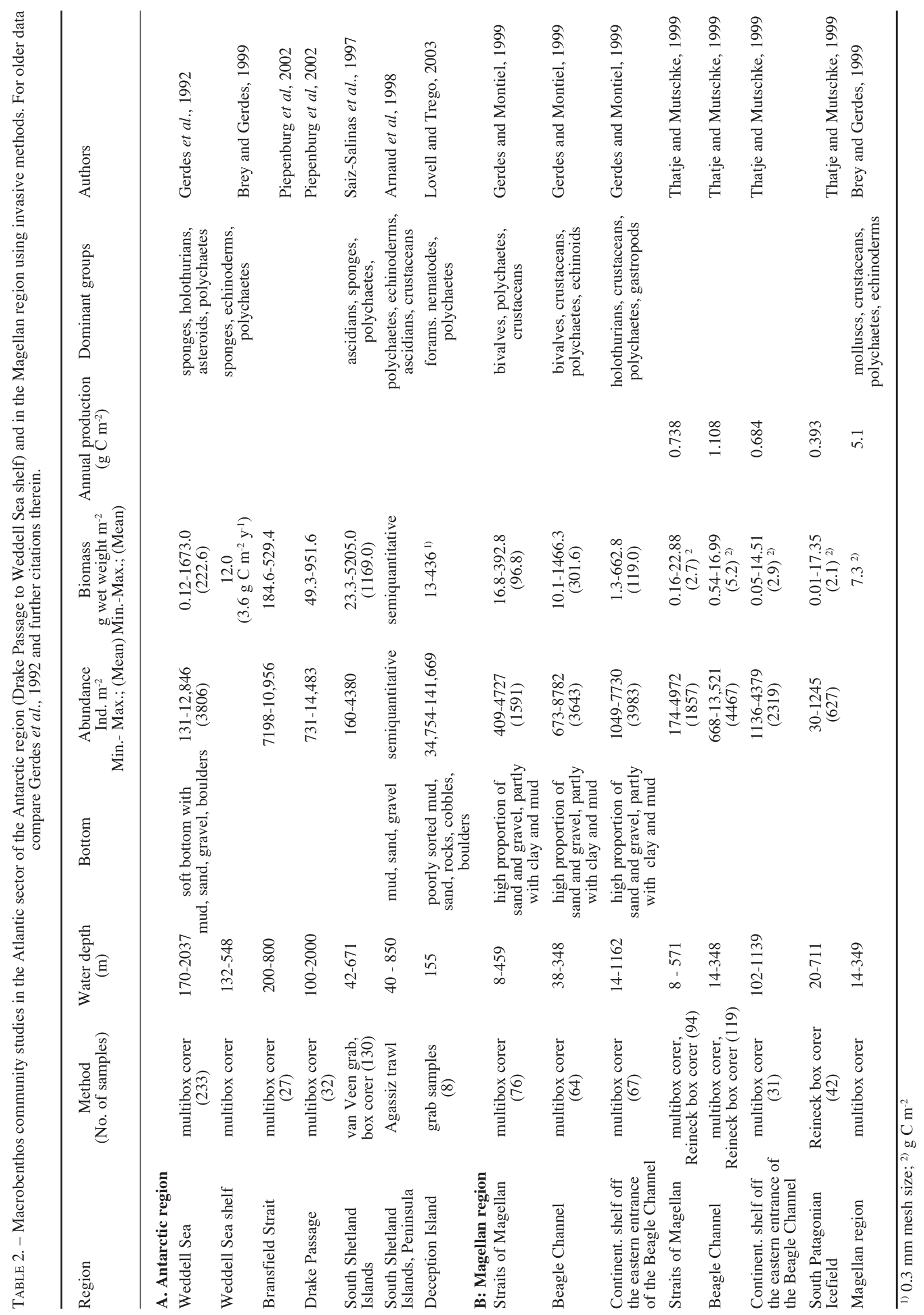



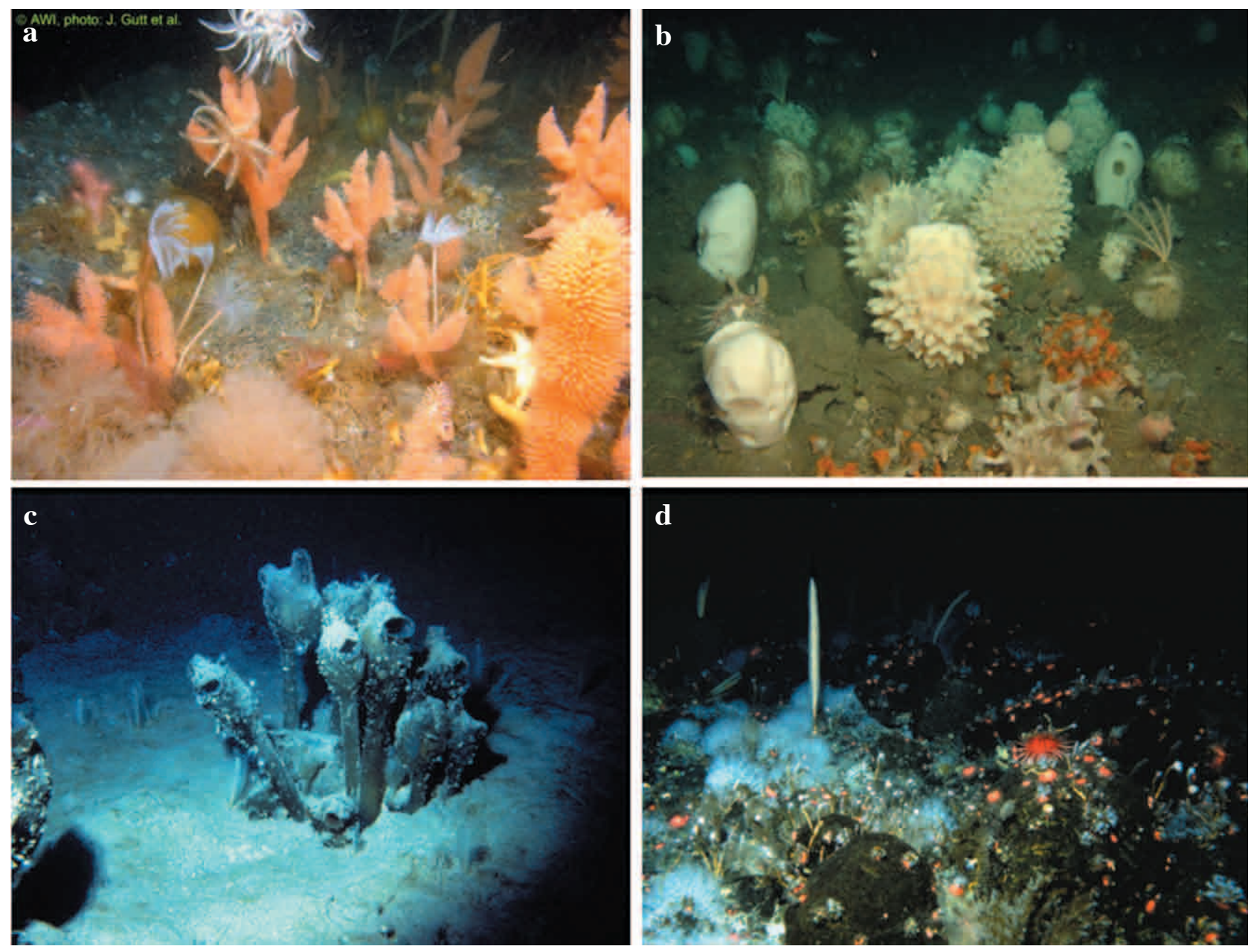

FIG. 5. - Typical aspects from Antarctic sessile suspension feeder communities. a) and b) gorgonian resp. sponge dominated (Weddell Sea shelf, 220 to $240 \mathrm{~m}$; photos WG J. Gutt); c) ascidian and pennatularian dominated (Potter Cove, King George I., 30 m, under heavy siltation from glacier; photo S. Kühne); d) hydrozoan and stoloniferan dominated (hard bottom with boulders and cobbles on the isolated Four Seasons Bank, eastern Weddell Sea, 70 m; photo: WG J. Gutt).

Antarctic (Arntz and Gorny, 1996; Chiantore et al., 2000; Heilmayer et al., 2003).

In their comparison of mega-epibenthic communities by UW video between Antarctic areas and NE Greenland (cf. above), Starmans et al. (1999) detected distinct differences in community structure between all areas. Sessile suspension feeders dominated the assemblages in the Weddell Sea, probably due to favourable bottom currents, but were scarce in the other Antarctic areas (Fig. 5). Another community analysis of mega-epibenthos with a UW camera on the Weddell and Lazarev Sea (99 to 1243 $\mathrm{m}$ depth), where faunistic patterns were best explained by a combination of water depth and geographic gradient, was done by Gutt and Starmans (1998). There was a positive correlation between the abundance of large sponges and the number of all other taxa, and a gradient from rich, diverse suspension feeder assemblages to poorer assemblages with a higher share of deposit feeders.
Cranmer et al. (2003) recently sampled a megafaunal epifauna community at $150-160 \mathrm{~m}$ in Port Foster (Deception I.) using UW camera and bottom trawl. Compared to the high Antarctic this community was rather poor, maybe due to volcanic eruptions and their effects described already earlier by Gallardo and Castillo (1969), Gallardo (1987) and Arnaud et al. (1998). Principal dominants were the echinoderms Ophionotus victoriae and Sterechinus neumayeri, but even these with low abundances. Lower importance of epi- vs. infauna at the Peninsula was found as published before (cf. Arntz et al., 1997). Faunal distribution turned out to be patchy similar to the high Antarctic (Starmans et al., 1999). In Arnaud et al.'s (1998) semiquantitative trawl study at the tip of the Peninsula, shallow (40-130 m) stations differed from deeper stations, besides the Deception I. stations mentioned above.

Due to recent Italian studies, Terra Nova Bay is now a second well-known area in the Ross Sea 
beside McMurdo Sound. These benthic communities differ substantially from the McMurdo assemblages $650 \mathrm{~km}$ to the south, which does, however, not necessarily reflect a latitudinal cline. Benthos community structure in Terra Nova Bay was studied from the intertidal to $150 \mathrm{~m}$ depth by Cattaneo-Vietti et al. (2000a) and at three sites between 450 and 810 m depth by Gambi and Bussotti (1999). Abundances were low (between 430 and 1040 ind. $\mathrm{m}^{-2}$, $0.5 \mathrm{~mm}$ mesh). Two sites showed more constant conditions and a high organic input from the water column, site 3 was highly disturbed. The benthos was predominantly small and the community likely to be immature.

Shallow hard bottoms to abt. $35 \mathrm{~m}$ in Terra Nova Bay were investigated by divers (Gambi et al., 2000). Polychaetes were the most abundant and diverse taxon followed by molluscs and amphipods. The area was widely covered by the macroalgae Iridaea cordata and Phyllophora antarctica. This zone receives frequent disturbance by sea ice.

Benthic communities in the Magellan region were studied by several authors (Table 2B). Information on community structure was published by Gutt et al. (1999), and on the impoverished fauna in the glacier region (South Patagonian Icefield) by Mutschke et al. (1996) and Thatje and Mutschke (1999). The specific fauna of the intertidal cobble and boulder fields in the Magellan Straits was described by Mutschke et al. (1998) and Ríos and Mutschke (1999). The fauna in this highly heterogeneous environment was richer than previously mentioned, but was dominated by few polychaete and mollusc species. Some species in this community have a wide Subantarctic distribution. Comparisons can be made with the stony beaches at Arctowsky (Jazdzewski et al., 2001) and King Sejong (Kim, 2001), both at King George Island. At Arctowsky, high abundance $\left(50,000\right.$ ind $\left.\mathrm{m}^{-2}\right)$ and biomass $(600 \mathrm{~g}$ wet wt. $\mathrm{m}^{-2}$ ) characterised the fauna. Biomasses in the Magellan community were similar $(330-3300$ g wet wt. $\mathrm{m}^{-2}$ ), but abundances were two orders of magnitude lower.

Barnes and de Grave (2001) investigated the "encrusting fauna" along 25 degrees of latitude from Tierra del Fuego to the Ross Sea. The authors found distinct Patagonian, Falkland (!) and Antarctic groupings. The Antarctic grouping revealed a cline from more northerly and shallow to more southerly and deeper sites (details in Barnes, 2005).

As within the Antarctic, densities and biomasses in the Magellan assemblages appeared rather vari- able. No distinct latitudinal gradients between both regions were detected (cf. Piepenburg et al., 2002), although the Magellanic fauna in general reveals higher production and productivity as pointed out by Brey and Gerdes (1999). Conversely, comparisons based on faunal composition allowed to distinguish different regions. Using trawl catches (Arntz et al., unpubl. data) and multibox corer samples (Gerdes and Montiel, 1999), the various subregions are clearly discernible even on the level of higher taxa. The Scotia Arc with its intermediate position reveals closer association to the Magellan fauna on the northern branch, whereas the southern branch was faunally more closely associated to the Peninsula fauna. South Georgia occupied an intermediate position. Adding the Weddell Sea shelf and Bouvet Island to the picture, average similarity was greatest between the high Antarctic and Peninsula and lowest between the Magellan region and Bouvet Island. Winkler (1994) found clear differences between the Scotia Arc incl. South Georgia and the high Antarctic Weddell Sea. The Scotia Arc and the Magellan region were mostly separated on species and genus level.

\section{Depth gradients}

Improved data are now available also on zonation. A report on the zonation of macroalgae by Quartino et al. (1998) complements former work by Klöser et al. (1996) in the Potter Cove, South Shetland Is. In this Cove, shallow macrofaunal zonation was studied by Sahade et al. (1998), confirming former findings of Dayton (1990) that communities are poor in very shallow water due to the influence of ice, storms etc., and increase in richness toward deeper water below the major impact of growlers, anchor ice and other disturbants.

Due to the ice shelves, almost no free shallow sites exist on the Weddell/Lazarev shelves. An exception is the Four Seasons Bank close to Kapp Norvegia, with distinct zonation belts (Arntz and Brey, 2005). Part of the species normally occurring at these depths may live under the ice shelves; e.g. Adamussium colbecki (cf. above), which is common in the Ross Sea (Chiantore et al., 2001).

A distinct allopatric depth distribution in the Weddell Sea was found in the serolids Ceratoserolis trilobitoides (shallow) and C. meridionalis (deep), and the aegids Natatolana oculata and N. obtusata (shallow) vs. $N$. intermedia (deep) (Summary Review in Arntz and Gutt, 1999). 
Cattaneo-Vietti et al. (2000a) found a clear depth zonation from the intertidal to $150 \mathrm{~m}$ depth in Terra Nova Bay: a rocky shore with a poor upper zone at 2-3 m, algal belts to $70 \mathrm{~m}$ with a diverse vagile fauna, Sterechinus and Odontaster; below a complex community dominated by sponges and cnidarians with high biomass and species richness. Soft bottoms start at 20-30 m depth. These communities are characterized by the bivalves Laternula elliptica, Adamussium colbecki, Yoldia eightsi and polychaetes (Tharyx cincinnatus and others). On muddy sands at $150 \mathrm{~m}$ depth other polychaetes and brachiopods dominate. Similar diversity of epibenthic habitats in the Weddell Sea was described by De Broyer et al. (2001a,b).

Significant differences among polychaete taxa distributed in shallow and deep waters of the Paso Ancho (Straits of Magellan) were found by Montiel et al. (2001). A distinct zonation in this area has also been reported for other benthic groups (Ríos and Mutschke, 1999; Ríos et al., 2003).

\section{Latitudinal and longitudinal exchange}

Environmental conditions change markedly on the latitudinal gradient but less on a longitudinal gradient, where exchange in the Southern Ocean is enhanced by the circular current systems and may occur over large distances (Beu et al., 1997). There is a latitudinal cline in the severity of environmental conditions (mainly ice and wind disturbance, with gradients in opposite directions; Barnes and Arnold, 1991). Traffic, e.g. of algae in a N-S direction across the Polar Front is presumably difficult unless there is ship transport (see below). The role of eddies (Glorioso et al., 2005) for latitudinal transport in the Scotia Arc has yet to be determined. Besides environmental factors, the dispersal abilities of larvae or drift stages also determine the success of exchange (Jablonski et al., 2003).

In shallow water, sharp differences were recorded north and south of the Polar Frontal zone in rock fauna, both in the number of species and in individual species distributions (Barnes and Arnold, 1991). The shelf fauna in the Scotia Arc revealed a predominantly Magellanic faunal composition on the northern branch of the Arc and a predominantly Antarctic one on the southern branch, as one would expect (Arntz and Brey, 2003), but there were exceptions, which may be due to shifts in the position of the frontal zone (cf. Fig. 2). In the Drake Passage, the southern slope is clearly Antarctic, howev- er with a better developed endofauna than in the high Antarctic whereas the typical high Antarctic epifauna is largely missing. Conversely, the northern slope is colonized by typical Magellan elements, which is best documented in the distinct southern limit of many decapod crustacean taxa (Arntz and Ríos, 1999; Arntz et al., 1999; Gorny, 1999; Lovrich et al., 2005).

Longitudinally, floating algae patches between the Argentinean coast and Burdwood Bank, >100 $\mathrm{km}$ offshore, and macroalgal communities at South Georgia demonstrate there is much eastward transport with the Circumpolar Current. However, the role of the South Sandwich Islands as a potential connecting agent for soft-bottom fauna seems to be low, similar to the shallows (Herdman and Discovery banks) due to their swept bottoms and strong currents (Arntz and Brey, 2003). Convey et al. (2002) have described the "extremely depauperate" conditions of the South Sandwich Islands with their remote position and lava or pumice bottoms, which were documented also in the LAMPOS cruise. Bouvet Island, lying even further east, was sampled during the BENDEX cruise; the first faunal analyses indicate Antarctic conditions and relations principally with the Antarctic Peninsula (Arntz and Brey, 2005; Arntz, in press). Theoretically, larvae or other dispersal stages arriving at Bouvet might travel with the Weddell gyre to the Lazarev or eastern Weddell Sea coasts, but so far there has been little faunal support for this hypothesis.

Circumantarctic transport is a prerequisite for the often cited "circumantarctic distribution" of many faunal elements, which is favoured by similar conditions around the entire continent and the (counter) clockwise current systems. A comparison of three Antarctic shallow-water sites (Atka Bay, Four Seasons Bank, Marguerite Bay) based on UW video transects distinguished the individuality of these sites; there was no greater similarity between the two former and the latter, despite very different distances for larval dispersal. The data also indicated that there is little exchange with adjacent deeper areas; otherwise the two former sites should also show greater similarity (Raguá-Gil et al., 2004). This poses the question how the few shallow sites in the Weddell Sea maintain their typical aspect of Antarctic shallow water fauna. Circumantarctic shallow-water exchange should be seriously hampered by the existence of the large ice shelves in the Weddell Sea and extended areas of permanent sea ice on the eastern side of the Penin- 
sula. However, the shallow-water bivalve Laternula elliptica was found at the isolated Hilltop site (Brandt et al. in Arntz and Gutt, 1999), together with many shallow-water hydroids (Gili, unpubl. data). Only 7 scallop (Adamussium colbecki) specimens have been found up to now in the entire Weddell Sea (Linse, pers. comm.). In summary, dispersal mechanisms of the shallow-water fauna are still far from clear.

\section{Invasions}

Due to its distinct environmental gradients, the Antarctic is an ideal natural laboratory under present global warming conditions. Recent arrivals of "alien" macroalgae at the Antarctic Peninsula were registered by Wiencke et al. (1998) in the Potter Cove, King George Island, comprising rare records such as Durvillea antarctica but also cosmopolitans (Wiencke and Clayton, 2002).

Recent literature mentions an increase of plastic debris as potential vehicles in the Circumantarctic Current (Convey et al., 2002; Barnes, 2002, 2005). These debris are sometimes preferred to macroalgae, which are known to transport invaders, and may represent a greater danger because of their "longevity" (Barnes, 2005). On the other hand, Convey et al. (loc. cit.) did not detect any evidence of colonisation by biota.

Another interesting aspect is the present attempt of the Decapoda, one of the taxa poor in species in the Antarctic, to return to the cold (Aronson and Blake, 2001; Anger et al., 2003; Thatje and Arntz, 2004; Thatje et al., 2005a). There seems to be an increasing mismatch towards the pole between environmental variables (decreasing temperatures, seasonally limited food availability) and typical decapod properties (see below). This mismatch seems to have been the reason for the expulsion or extinction of Antarctic decapods in the Tertiary as well as for the failure of recolonisation in recent times, despite obvious pressure from the Magellan region (Arntz et al., 1999; Thatje et al., 2003). In the case of continued global warming, this pressure from other decapod taxa including the brachyurans is likely to increase. This suggestion is supported by recent detections at the Antarctic Peninsula of 9 "alien" specimens of meroplanktonic larvae belonging to Magellanic decapods (Thatje and Fuentes, 2003) and the find of the North Atlantic brachyuran Hyas araneus reported for 1986 by Tavares and Melo (2004; however, see also Thatje et al., 2005a for discussion).

\section{Specific Antarctic traits, strategies and adaptations}

\section{Reproductive strategies and population dynamics}

Reproductive strategies change along latitudinal gradients, which is mainly due to differences in temperature, primary production cycles and food availability. Already before IBMANT II, there was a substantial literature describing special Antarctic characteristics, see e.g. Pearse et al., 1991; Clarke, 1992; Arntz et al., 1992, 1994 and refs. therein. Specific polar characteristics had been identified, but it was also clear that there were numerous exceptions, and that very different adaptations to polar conditions had been developed.

One of the traditionally controversial issues is "Thorson's rule" (for the background see Clarke, 1992; Pearse, 1994; Arntz and Gili, 2001). StanwellSmith et al. (1999) contributed a very important paper on the occurrence of pelagic marine invertebrate larvae in shallow water at Signy Island, where they registered a total of 181 pelagic larval types, many more than ever found in Antarctic waters. However, even this number is low in view of the high benthic species number in these waters (see above), and densities were extremely low in comparison with those in temperate regions. For most described morphotypes species identification remains unclear and the number of species with certain larval types may be biased by considering subsequent ontogenetic stages of the same species (Arntz and Gili, 2001). Another recent approach in Admiralty Bay (Freire et al., 2005) yielded somewhat higher meroplanktonic larval numbers in shallow water, but still much less than at lower latitudes. In a first attempt to evaluate conditions in deeper, high Antarctic waters, a Dutch-German team found extremely low numbers of meroplanktonic larvae off Kapp Norvegia (Arntz and Brey, 2005; Lavaleye et al., 2005), which principally supports Thorson's rule. Furthermore, many of the pelagic larvae found hitherto are lecithotrophic and occur year round, and some (such as the Caridea) have a high starvation resistance (cf. Thatje et al., 2004, 2005c).

Why do some of the most abundant Antarctic shallow-water species deviate from the more frequently found patterns of non-planktotrophic development, and have become broadcasters (Poulin et al., 2002)? These broadcasters include A. colbecki, L. elliptica, O. validus, O. meridionalis, S. neumayeri, Porania antarctica, and Ophionotus victoriae 
whereas the vast majority of other species are brooders or lecithotrophic. The authors explain the apparent ecological success of the first group by advantages in recolonisation e.g., after iceberg disturbance whereas the other species rather reflect an evolutionary success, permitting them to survive under conditions of glaciation. The question is, of course, whether demersal drift stages or lecithotrophic larvae would not serve the same purpose.

Contrary to the Antarctic, meroplanktonic larvae of benthic invertebrates are very common in the Straits of Magellan and the Beagle Channel, and many of them are planktotrophic with either extended or abbreviated development (Thatje et al., 2003). The meroplankton community studied in November 1994 was dominated by decapod crustacean larvae, followed by polychaetes, echinoderms, cirripedes and molluscs.

Many individual studies have recently shed more light on reproductive strategies and population dynamics along the cold temperate Magellan to high Antarctic gradient. Growth of some endemic Antarctic macroalgae is restricted to very low temperature values $\left(0-5^{\circ} \mathrm{C}\right.$, in some cases $\left.10^{\circ} \mathrm{C}\right)$, much lower than for cold-temperate species (Wiencke and tom Dieck, 1989, 1990; Bischoff-Bäsmann and Wiencke, 1996; Gómez et al., 1998). Light requirements for the completion of the life cycle of several Antarctic algal species are very low. Reproduction and growth of early stages takes place under dim light in winter (Wiencke, 1990a,b; 1996). The photosynthesis apparatus remains intact in some species (e.g., Iridaea chordata) during prolonged darkness but not in others such as Palmaria decipiens (Weykam et al., 1997). Day length strongly governs the seasonal growth of many algal species (Wiencke, 1990a,b), and a minimal window of 10 days with 5 hours of light is required for formation of gametangia and gametes in large brown algae such as Desmarestia anceps (Wiencke et al. 1996), which explains the drop-out of many species on the latitudinal Ross Sea gradient towards McMurdo (Wiencke and Clayton, 2002). Similar studies in the Magellan region are necessary to extend the latitudinal aspect to the north.

Decapod reproductive biology has now been studied in the Antarctic and Magellan regions along a wide latitudinal range of 23 degrees of latitude (Arntz and Thatje, 2002; Thatje et al., 2003, 2004). Growth was found to be slower, and mortality lower in Antarctic caridean shrimps than in related species living at lower latitudes. First maturity occurs at an advanced age and size, and longevity is very high (up to $10 \mathrm{yr}$ or more) in the Weddell Sea (Gorny et al., 1992). The caridean shrimps have adapted to the latitudinal gradient by reducing fecundity, better equipping their fewer eggs, and hatching as large, morphologically advanced larvae with a distinct starvation resistance (Gorny et al., 1992, 1993; Romero et al., 2003 a; Thatje and Lovrich, 2003, Thatje et al., 2004). However, the step to complete lecithotrophy has not yet been undertaken by any caridean species except Sclerocrangon boreas in the Arctic, see Thatje et al. (2003), and seems to be a phylogenetic constraint in marine representatives of the taxon. Adaptation to increasing seasonality in this group has been achieved mainly by reducing the pelagic larval phase, e.g. in Campylonotus vagans (Magellan, Thatje and Lovrich, 2003) and Chorismus antarcticus (Antarctic, Bruns, 1992; Gorny et al., 1992; Thatje et al., 2003). Further characteristics are a decrease of moults and larval instars towards the pole, reduced energetic losses in very thin cast exuviae (Thatje et al., 2003) and low $\mathrm{Mg}^{2+}$ concentrations in the haemolymph (Frederich et al., 2000, 2001). The latter has, however, so far been confirmed only for adult stages. Adaptation of reptant decapod taxa to all these characteristics has been less efficient, and particularly the extended larval development and low starvation resistance may have caused evolution to select against Antarctic reptants (Thatje et al., 2003, 2005a). An exception is the anomuran family of lithodid crabs, which besides the deep sea has conquered also high latitudes in both polar regions. Southern Ocean lithodids combine fully lecithotrophic larvae equipped with sufficient lipid reserves with strongly reduced demersal instars and a high tolerance against the cold (Lovrich and Vinuesa, 1996; Anger et al., 2003, 2004). However, this tolerance may not yet be perfect, as lithodids have not been found on the very cold high Antarctic shelf with temperatures of less than $-1.8^{\circ} \mathrm{C}$ (Fig.6) while the temperature threshold for successful larval development seems to be around 0 to $1^{\circ} \mathrm{C}$ (for temperature thresholds and discussion see Anger et al., 2003, 2004; Thatje et al., 2005a).

A number of interesting studies has been undertaken further north along the Chilean Pacific coast, which are related to the subject of decapod coldwater adaptation. These studies (Brante et al., 2003; Fernández et al., 2003) tried to integrate the cost of brooding in the reproductive effort to obtain a more 


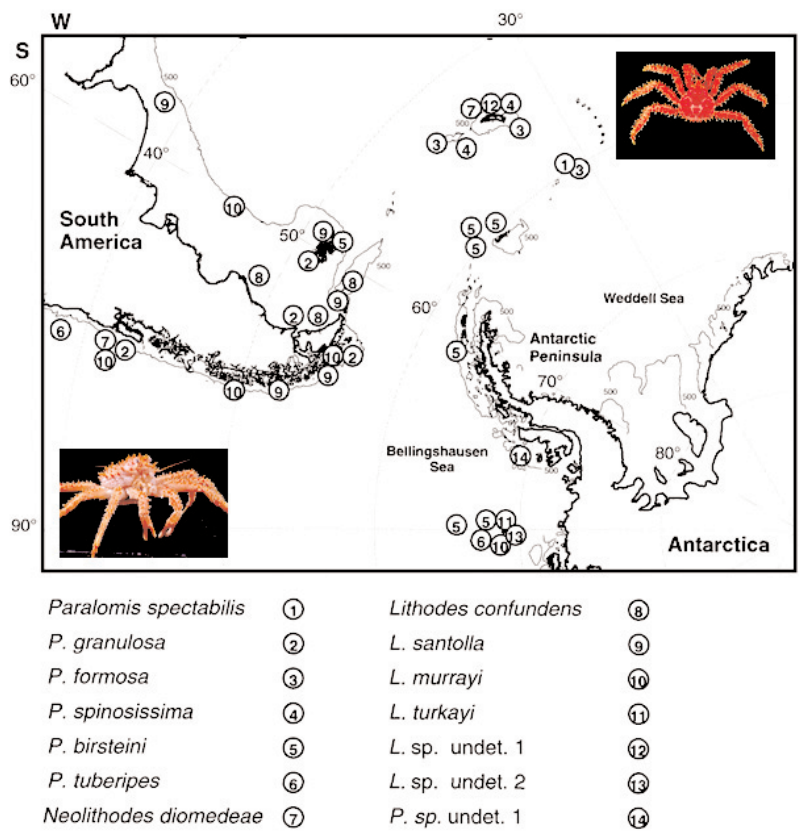

FIG. 6. - Distribution of lithodid crab species (Anomura) caught hitherto off southern South America, the Falkland Is. (Malvinas), along the Scotia Arc and the Antarctic Peninsula, and in the Bellingshausen Sea. Despite hundreds of hauls taken, not a single crab has ever been caught in the icy waters of the Antarctic continental shelf. (From Thatje and Arntz, 2004).

reliable estimate of reproductive investment, also along the latitudinal gradient. Temperature affects the period of embryo ventilation events, maternal abdominal flapping frequency, embryo losses during the brooding period, and the cost of embryo ventilation per unit of time. Crab females are able to adjust oxygen supplies to embryos according to their needs (Baeza and Fernández, 2002), but this may affect investment in reproduction, and might have important implications on larval survival and development.

While the quality of reproductive output changes with latitude towards a better outfit of less eggs and more lipid investment per embryo, the cost of embryo ventilation decreases with temperature, suggesting a trade-off between investment in eggs and the cost of providing oxygen to the embryos at different temperatures (latitudes). Should this not favour also the reptants, which are missing in cold water? Apparently the combination of very slow embryonic development with a mismatch between reduced metabolism and low food availability in the larval phase (Thatje et al., 2003), combined with physiological constraints, counteract this advantage, as is the case also in the circumantarctic genus Munida, which has not conquered Antarctic waters despite an enormous dominance of up to $80 \%$ on the Magellan side (Tapella et al., 2002; Arntz et al., 1999).
At least some Antarctic suspension feeders have similar growth and reproduction rates to those of their temperate relatives (Orejas et al., 2000) due to efficient food assimilation. Substantial progress has been made in elucidating reproductive strategies in this traditionally neglected group, which dominates the high Antarctic benthos over wide areas.

Antarctic ascidians are hermaphrodites and have lecitotrophic larvae. The genera Cnemidocarpa, Molgula and Pyura in Potter Cove exhibit strong seasonality in their reproduction. M. pedunculata and $C$. verrucosa reproduce in winter, $P$. setosa in summer. Paradoxically, the two winter-spawning species are the two most successful species in this ecosystem. Perhaps they are avoiding salp predation on the larvae, which is more intense in summer (Sahade et al., 1998). Combining results from colonisation panels and respiration measurements, Kowalke et al. (2001) showed ascidians from Potter Cove to have high growth rates, favoured by a low basal metabolism and extended longevity. These properties, together with their ability to survive under intense sedimentation, make them effective competitors among benthic suspension feeders.

In gorgonians the number of eggs per mature polyp is in the same order of magnitude as in nonpolar areas. During autumn in some female polyps larvae ready to be released were found together with oocytes in early stages of development, suggesting an extended development period from early spring to late austral summer. Thus these organisms might be in a continuous reproductive state, which would enable them to recruit successfully at any time, e.g. in areas disturbed by icebergs. This would explain, too, why Primnoisis sp. is among the first dwellers in iceberg scours. Their larvae are not pelagic but might function as drift stages (Orejas, own obs. EASIZ II).

Two size classes of oocytes in different developmental stages were found in Ainigmaptilon (Orejas et al., 2002) in summer and autumn. The apical and medial parts of the colonies showed highest fecundity. The relative frequency of the largest size class decreased in the autumn samples. Ainigmaptilon is characterized by an extended oogenesis period $(>1 \mathrm{yr})$. Spawning seems to be delayed until the autumn-winter season, as was also observed in some Thouarella during EASIZ III. No larvae of this species were detected in summer and autumn. The absence of larval stages during autumn was surprising, considering that many octocoral species had larvae ready to be released, leaving the reproduction of Ainigmaptilon still as a mystery. The type of fertil- 
ization (external or internal) could not be determined. Our data do not allow us to state any special Antarctic features in the reproductive biology of Ainigmaptilon, although we think they exist.

Bryozoans have lecithotrophic larvae, which spend a very short time in the water column before settlement. The number of larvae produced daily is very small. The larvae of some species are incubated for up to 10 months before being released (Barnes and Clarke, 1998). Reproduction time in the Antarctic is summer and autumn (Zabala et al., 1997; Barnes and Clarke, 1998; Bader, 2002).

Cellaria incula growth and age was analysed by stable carbon and oxygen isotope analysis (Brey et al., 1999). The growth of one complete branch of this species takes one year; maximum age of a colony is likely to be more than $14 \mathrm{yr}$. P/B was 0.67 , the highest value measured for any benthic invertebrate south of $62^{\circ} \mathrm{S}$. Similar to another bryozoan, Melicerita, this fast-growing species is a pioneer in the recolonisation of iceberg scours (see below).

In a latitudinal comparison of pectinids, Heilmayer et al. (2003) studied the Antarctic scallop Adamussium colbecki in relation to (a.o.) the Magellan species Zygochlamys patagonica. Despite the fact that growth efficiency in pectinids was found to decrease at higher temperatures, the absolute growth of A. colbecki was found to be much slower than that of the Magellan species. A. colbecki attains a high age (Chiantore et al., 2003, Heilmayer et al., 2003 and references therein). Growth of the Antarctic shallowwater bivalve Laternula elliptica was studied by Voigt (2004) using material from King George Island. He reconstructed growth over 40 years (1961-2001), revealing interannual growth fluctuations correlated with changes in sea surface temperatures and ENSO indices. Very slow embryonic development of Antarctic molluscs had already been shown by Hain and Arnaud (1992) before IBMANT I.

The polychaete families Polynoidae and Sabellidae have a greater variability in reproductive features than assumed hitherto: Harmothoe spp. brood their eggs under the elytra, Myxicola cf. sulcata incubates its embryo within the tentacle crown (Gambi et al., 2001).

Very slow embryonic development rates were found in the three echinoderms $O$. validus, $O$. meridionalis and S. neumayeri, 2-20 times slower than their temperate or tropical relatives (StanwellSmith and Peck, 1998). The authors proposed a window of optimal temperatures between $+0.2^{\circ} \mathrm{C}$ and $+1.7^{\circ} \mathrm{C}$ for $S$. neumayeri embryo development and viability. Embryos of further two species are released in winter, when water temperature is constantly below $-1.6^{\circ} \mathrm{C}$. Temperature, not larval food supply and predation during planktonic phases is the dominant ecological factor for these species.

Similar to most invertebrates, growth was found to be very slow and maximum age high in high Antarctic notothenioids (Morales-Nin et al., 2000) and zoarcids from the Peninsula (Brodte, 2001).

\section{Susceptibility of living resources (decapods, molluscs) to exploitation}

The vulnerability of exploited or exploitable invertebrate stocks to fisheries is intimately related to the population dynamics of the respective target species. Three of the Antarctic caridean shrimp species (C. antarcticus, $N$. antarcticus and $N$. lanceopes) occur in appreciable quantities (see, e.g. Arntz and Gorny, 1991). However, their late maturity, low fecundity and slow growth (Gorny et al., 1992) do not encourage a fishery, and the damage to be expected from a trawl fishery would be much greater than the potential benefit (Arntz et al., 1994).

After heavy decimation of the spawning stock by the fishery, the population dynamics of lithodid crabs (L. murrayi, $P$. granulosa) have been studied in the Beagle Channel by various authors, mainly from Argentina (Lovrich and Vinuesa, 1996; Lovrich, 1997). Chilean landings of these two species in the XI and XII region have been oscillating between about 3000 and $9000 \mathrm{t}$ annually between 1999 and 2004 (SERNAP, 2005). Notwithstanding their ability to adapt to (sub)polar conditions, this group is quite vulnerable to overfishing. It would be interesting to study the lithodids detected recently in the high Antarctic (Arana and Retamal, 1999) to check whether this taxon also reveals the kind of latitudinal reproductive gradients found in caridean decapods (Gorny et al., 1992). An exploratory fishery on lithodids, mainly $P$. spinosissima, off South Georgia in 1994-96, with a precautionary TAC of $1600 \mathrm{t}$, yielded only about 500 t (CCAMLR, 1994, 1996; Collins et al., 2002), but seems to have decimated the stock to a very low level. Exploitation has since been restricted to occasional bycatches in the roundfish fishery (Fanta, pers. comm.).

Another anomuran taxon, the squat lobster Muni$d a$ spp., is distributed in the Magellan region incl. the northern branch of the Scotia Arc until South Georgia (Romero et al., 2003a) but is missing in Antarctic waters, probably due to its reproductive 
characteristics which have recently been studied by Tapella et al. (2002) and Thatje et al. (2003). This very common genus is of potential use as a fisheries resource in Chile and Argentina.

The Antarctic scallop (A. colbecki) is one of the key species in the Ross Sea (Heilmayer et al., 2003), whereas only few scattered individuals have so far been found in the Weddell Sea. Due to its consumption and production this active suspension feeder seems to play a significant role in the trophic web of the Ross Sea shelf. However, it would be very vulnerable to exploitation compared to other pectinids because of its very low overall growth performance and productivity.

Magellan bivalve resources include the scallops Chlamys vitrea and Zygochlamys patagonica and the mussel Aulacomya ater, all of them being exploited in Chile with 1999-2004 catches in the XI + XII region oscillating between about 100 and $2000 \mathrm{t}$ (SERNAP, 2005), and several "almejas" (mostly Veneridae: Venus antigua, Retrotapes exalbidus, Tawera gayi) as potential resources. The gastropod Adelomelon sp. is gradually becoming exploited on the Atlantic side (Cledón, 2004); Volutidae (Harpovoluta) also occur in the Antarctic but are too rare to serve as a potential resource. Other gastropods, above all Muricidae and Buccinidae (Trophon geversianus, Argobuccinum spp.), do not play a great role commercially at this time but exploratory culture has been started for some species that might replace the reduced Concholepas stocks in Chile (C. Gallardo, pers. comm.).

Clearly the Magellan benthic ecosystem (Fig. 7) hosts many more potentially exploitable resources, at least for human consumption, than the Antarctic. Altogether there is increasing evidence, however, that all benthic crustacean and most mollusc species of potential commercial value in the Antarctic and along the southern border of the Magellan region deserve special care, with increasing tendency toward the high Antarctic, if exploitation is envisaged. The virtual destruction of most Antarctic fish stocks, which is presently culminating with the severe reduction of the last commercially important species Dissostichus eleginoides and D. mawsoni (Collins et al., 2003; CCAMLR, 2005) should be taken as a warning indicating the vulnerability of cold water stocks to exploitation.

\section{Tolerance limits and other adaptations}

Much progress has been made in understanding physiological mechanisms of temperature adapta-
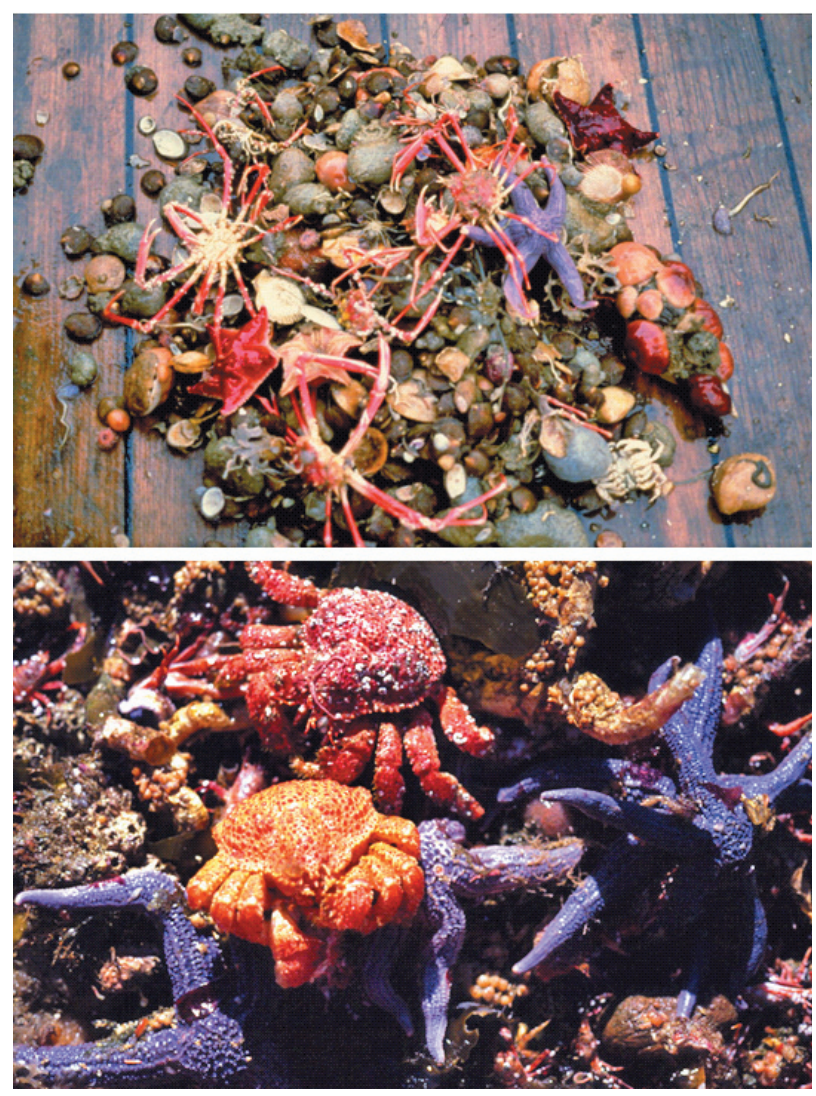

FIG. 7. - Trawl catches in the Magellan region are similar to high Antarctic catches in the dominance of echinoderms, but are quite different in the often striking appearance of large brachyuran and anomuran decapods and bivalves. Brachiopods are occasionally dominant in both areas. Canal Brecknock, $480 \mathrm{~m}$ (above) and I. Pícton, $63 \mathrm{~m}$ (below); photos W. Arntz.

tion; how did climate variability in the past influence biogeography and evolution of marine ectotherms? These questions are dealt with in the review by Pörtner et al. (2005) and recent work by Peck (2001) and Clarke (2003b).

Oxygen supply in the tissues may determine thermal tolerance and limit maximum size. A latitudinal cline in maximum size of amphipods due to better oxygenation and the architecture of the vascular system in cold water was detected by Chapelle and Peck (1999). Maximum sizes showed an inverse relationship to water temperature, which may explain the large size of many Antarctic amphipods. It should be noted, however, that the greater number of Antarctic amphipod species is rather small.

The benthic diatoms Gyrosigma subsalinum and Odontella litigiosa exhibited extremely low upper survival temperatures of $5-7^{\circ} \mathrm{C}$ in Potter Cove, and growth occurred only in the narrow range of $0-7^{\circ} \mathrm{C}$. Optimal temperature for growth was $0^{\circ} \mathrm{C}$, for photosynthesis $5^{\circ} \mathrm{C}$. The northern limit of G. subsalinum is the $4^{\circ} \mathrm{C}$ summer isotherm, corresponding to the 
northern limit of the Antarctic, whereas $O$. litigiosa could also live in the Subantarctic up to the $7^{\circ} \mathrm{C}$ summer isotherm (Longhi et al., 2003).

Surprisingly high values of lethal temperatures in Antarctic Peninsula molluscs $\left(\mathrm{L}_{\mathrm{t} 50}\right.$ of Laternula elliptica, $14.9^{\circ} \mathrm{C}$ and Nacella concinna, $15.5^{\circ} \mathrm{C}$ ), which are not likely to be reached by global warming in the near future, were found by Urban (1998). Reburial temperatures, however, were much lower $\left(\mathrm{B}_{\mathrm{t} 50}\right.$ of L. elliptica: $\left.3.6^{\circ} \mathrm{C}\right)$. Similar temperature threshold patterns have been suggested to be valid in lithodid crabs (Anger et al., 2003, 2004); so $\mathrm{L}_{\mathrm{t} 50}$ may not be an adequate measure to indicate limits of survival (cf. Abele, below).

Distribution limits of macroalgae are not only set by ice abrasion and substrate, or biological factors such as competition (Klöser et al., 1996) and herbivory (Iken, 1996; Iken et al., 1998) but also by depth due to metabolic prerequisites. The upper distribution limit is determined by the capability for dynamic photoinhibition, a process by which excessively absorbed photosynthetically active radiation is dissipated as heat (Hanelt, 1996, Bischof et al., 1998). For the lower distribution limit the low light requirements for photosynthesis and growth are of primary importance. Some algae are unable to inhabit depths greater than $30 \mathrm{~m}$. A critical daylight length during which algae are exposed to light saturated irradiances may be the key factor setting the lower distribution limits of these species (Gómez et al., 1998).

The acclimatisation of Antarctic macroalgae to seasonal changes in light was investigated by Lüder (2001), using the photosynthetic apparatus of the alga Palmaria decipiens in culture experiments.

Light conditions also seem to play a major role for sponges in the Terra Nova ecosystem, between 70 and $120 \mathrm{~m}$ depth (Cattaneo-Vietti et al., 2000b). They seem to survive oligotrophic conditions in winter by direct uptake of diatoms, which live for a long time in the sponge tissue. Spicules in the hexactinellid Rossella racovitzae conduct light as natural optical fibres and thus provide the diatoms with light.

Apart from specific Antarctic problems such as extremely low temperatures, seasonality of primary production and food shortage, stress caused by global warming and increased UV-B radiation has become an important issue in recent years. While the major part of the continent does not yet show signs of warming, the Antarctic Peninsula has experienced a distinct temperature increase by $>1.5^{\circ} \mathrm{C}$ since the middle of the 20th century (Vaughan et al., 2003), and the "ozone hole" continues to stress ben- thic life in shallow water. Both the effects of warming and of increased radiation are particularly interesting to study on the Magellan-Antarctic gradient.

Oxidative stress may be caused by hypoxia, hyperoxia, intoxication, high temperatures, but also by UV irradiation, liberating reactive oxygen species or leading to a dysfunction of the cellular antioxidant defense system (Abele et al., 1998). Oxidative stress is critical for membrane integrity, may cause a disturbance of subcellular structures and eventually limit survival. In the Potter Cove (King George Is.) the effects of temperature increments causing oxidative damage in inter- and subtidal molluscs (Yoldia eightsi, N. concinna) were studied. "Critical temperatures" for survival, Tc of L. elliptica were $9^{\circ} \mathrm{C}$, of $Y$. eightsi $4-5^{\circ} \mathrm{C}$. No Tc was given for $N$. concinna, however oxidative stress occurred at $4^{\circ} \mathrm{C}$, and mortality at $9^{\circ} \mathrm{C}$, which seems very low for an intertidal animal. Paradoxically, intertidal animals seem to be more sensitive to warming than subtidal ones.

Under increased UV-B radiation, amphipods seek protection under algae. Unprotected in the laboratory they react with stress and higher mortality (Obermüller et al., 2003). Hernando et al. (2001) identified repair and protective mechanisms that allow Antarctic algae to survive and reproduce under increased UVB radiation. Despite the existence of such mechanisms, the combination of rising temperatures and persistence of the ozone hole is a severe threat to Antarctic and Magellanic benthos, which may induce major changes in the near future.

\section{Trophic strategies and coupling between subsystems}

Trophic strategies on the Magellan-Antarctic gradient are mainly determined by a change from dominant endo- to dominant epifauna and shorter primary production cycles towards the pole. The energy flow through the Weddell Sea benthos was shown to be more diverse than in the Magellan region (Brey and Gerdes, 1999). While information on feeding strategies and food webs in the Antarctic has increased considerably in recent years, little new information has been created from the Magellan region (Schnack-Schiel and Isla, 2005).

The traditional view of Antarctic sessile suspension feeder communities feasting during the short period when fresh primary production is available from the algal blooms and "hibernating" without food uptake during the rest of the year became doubtful, when Barnes and Clarke (1995) demon- 
strated that certain Antarctic shallow-water suspension feeders are able to feed throughout the year with only short periods of starvation. They feed on pico- and nanoplankton (between 0.2 and $20 \mathrm{~mm}$ ), which in these areas dominate the water column and the sediment most of the year (Clarke and Leakey, 1996; Cripps and Clarke, 1998) whereas phytoplankton (microplancton) is dominant only during short periods.

Similar finds by Orejas et al. (2001) on the deeper shelf of the high Antarctic Weddell Sea made it likely that the algal blooms rather play an indirect role through sedimentation, resuspension and advection (Gili et al., 2001), and that trophic strategies under the pack ice are similar to those found in shallow water. In late summer (Feb/Mar), food input from the pelagial to the benthic system is rich as indicated by ROV pictures (Arntz and Gutt, 1997, Summary Review). However, food analyses of benthic suspension feeders in EASIZ I and II revealed that apart from some specific zooplankton feeders such as certain hydrozoans (Gili et al., 1998) most benthic organisms made little use of these larger particles, despite their abundance. Instead, they ingested the food web based on bacteria, nano- and picoplankton, unicellular organisms and organic detritus contained in the seston (Orejas et al., 2000; Gili et al., 2001).

In the context of glaciation, pack ice cover must be considered an important evolutionary factor, as it may have prevented new production in the water column, and may have stimulated suspension feeders to rely more on resuspended and advected material (Arntz and Gili, 2001). This would indicate that benthic suspension feeders in these areas still maintain a feeding strategy, which served during glaciation, despite the fact that under present conditions fresh algal food is available during certain periods of the year. Towards the Magellan region, this fresh food window is open for most of the summer half.

The "new view" of less dependence on the short seasonal microalgal blooms in the Antarctic has now been supported by various studies. A wide range of diets was found in four cnidarian genera in the Antarctic, the hydrozoans Oswaldella and Tubularia; the stoloniferan Clavularia, and the anthozoan Anthomastus, indicating opportunistic behaviour by feeding on all available food sources and sizes (Orejas et al., 2001). Main food of Tubularia and Anthomastus was zooplankton, Oswaldella fed on the fine fraction of seston, and Clavularia on resuspended material. In the two Antarctic octocorals
Primnoisis antarctica and Primnoella sp., feeding experiments showed that components of seston, including the fine fraction of suspended organic matter, are an important part of the diet (Orejas et $a l ., 2003)$. In terms of the number of cells captured, the diatom Fragillariopsis was the most important food for Primnoisis whereas dinoflagellates dominated in Primnoella. Mesozooplankton was very scarce in the diet of these gorgonians but may have some importance because of its high carbon content. Despite their relatively small contribution to biomass, hydrozoans capture large amounts of zooplankton and seston, and play an important role in transferring energy from the pelagic to the benthic ecosystem (Gili et al., 1998). Not all of them are carnivores although Tubularia ralphii, an exception in that it feeds on large particles, clearly is one: its predation rate was estimated at 1790 prey items $\mathrm{m}^{-2} \mathrm{~d}^{-1}$, with a diet consisting entirely of planktonic copepods (Arntz and Gutt, 1999, Summary). Conversely, the Subantarctic hydrozoan Silicularia rosea-the other large particle feeder-feeds on benthic diatoms (Gili et al., 1996). Another unusual trophic strategy was reported of the hydrozoan Hydractinia angusta living on Adamussium shells in Terra Nova Bay (Cerrano et al., 2000): It ingests tube feet and pedicellariae of sea urchins (Sterechinus) grazing on the scallop shell, as well as masses of diatoms living in a kind of symbiosis in the hydrorhiza of the colony. There may be more examples for the trophic versatility of Antarctic suspension feeders.

The varied diet composition typical of opportunists, together with their feeding on the fine fraction of seston as indicated by experiments, reveals that passive suspension feeders in deeper waters, too, are likely to continue feeding under winter conditions in the high Antarctic.

In Terra Nova Bay carbon flux to the benthos is enhanced by katabathic winds, favouring the development of benthic detritus, and of large active suspension feeders such as Laternula elliptica (Povero et al., 2001). This species is of great importance for benthopelagic coupling through biodeposition, as it enhances particle fluxes to and from the seabed, and has an important output of nutrients through excretion (Mercuri et al., 1998).

Stable isotope ratios have turned out to be increasingly useful for trophic modelling attempts in the Antarctic. $\mathrm{N}$ isotopes serve as indicators of a consumer's trophic position relative to that of species occupying lower trophic positions. Wide ranges in $\delta^{15} \mathrm{~N}$ ratios in most benthic taxa of Antarc- 
tic food webs indicate feeding across a range of trophic levels. This is due to the high amount of omnivory, the ability of vertical niche expansion, the presence of multiple carbon sources, and the 3dimensionality of the Antarctic benthos. The hypothesis that 3-dimensional habitats support longer food chains than 2-dimensional habitats has not been fully explored (Briand and Cohen, 1987; Pimm et al., 1991), but it is consistent with recent findings that in Antarctic food webs the distance from phytoplankton to pelagic top predators is 2.5 trophic levels, whereas the distance to benthic top predators is about 3.5 trophic levels. At the Antarctic Peninsula seaweeds provide an important food source in the web, whereas krill Euphausia superba is important as food in the pelagic Weddell Sea food web (U. Jacob, unpubl. data).

A stable isotope approach to the eastern Weddell Sea food web, with a focus on 90 amphipod species, was made by Nyssen et al. (2002). In 8 amphipod species isotopic composition was compared with their previously described gut contents. Feeding strategies seem to remain stable over time. Amphipods do not belong to one trophic category but display a continuum of feeding modes from suspension feeders to scavengers.

Recent studies on the role of amphipods in the Antarctic food web, including aspects such as trophic guilds, were summarized by De Broyer et al. (2003). Other recent publications of the Belgian group include Dauby et al., 2001a (trophic diversity of amphipods); Dauby et al., 2001b (importance of amphipods as predators); and Dauby et al., 2003 (amphipods as food for higher trophic levels). Many of the $>820$ known species are of paramount importance as food to many invertebrate and vertebrate taxa. Annual consumption of amphipods was estimated at 60 million $\mathrm{t}$ (which would make them the second most important taxon after the krill (Dauby et al., 2003)). Feeding of amphipods in the Potter Cove, King George Island was investigated by Momo et al. (1998). Most amphipods were detritivores and scavengers, herbivores were few despite large macroalgal stocks in the area.

Trophic relations between macroalgae and herbivores in the Potter Cove were studied by Iken et al. (1998). The herbivorous gastropod Laevilacunaria antarctica is not deterred by polyphenolic extracts of brown algae. Towards higher latitudes, where macroalgae are missing, herbivory gives way to specialized feeding strategies and increased necrophagy (Arnaud, 1970).
High Antarctic caridean shrimps, despite very different mandible shapes and stomachs, and despite living in different habitats, seem to make an exception (Storch et al., 2001). They had ingested very similar food, and there did not seem to be a relation, either, to life style or habitat preferences; these shrimps were truly omnivorous. Shrimps in the Magellan region seem to be omnivorous, too, but detrital food there is derived from terrestrial sources (Romero et al., 2003b). Comoglio and Amin (1999) studied the stomach contents of lithodid crabs in the Beagle Channel.

Schrödl's (2003) book on South American sea slugs contains notes on their biology. Similar monographs on other Magellanic and Antarctic taxa are urgently required.

Fish in the food web off the Antarctic Peninsula are important inshore benthos and zooplankton feeders, linking the upper and lower levels of the food web (Barrera-Oro and Casaux, 1998; BarreraOro, 2002). Olaso et al. (2000) studied the trophic ecology of the family Artedidraconidae in the eastern Weddell Sea, and Vacchi et al. (2000) investigated coastal fish predation (incl. its impact on the benthos) in the Ross Sea.

Few studies seem to exist on mutualisms. Sirenko (2002) makes an exception, describing the symbiosis between the gastropod Dickdellia labioflecta and pycnogonids.

\section{The role of disturbance and its significance for biodiversity}

Ice as a disturbant still plays a certain role in Magellan waters (cf. Fig. 1), but is decreasing in importance due to global warming and becomes increasingly more important towards the pole. In the Magellan region, local scouring effects of small icebergs or growlers may occur in the shallow water of some fjords, but such effects have not been reported. There are, however, distinct ice effects off the Patagonian ice fields caused by low salinity due to freshwater input (Dávila et al., 2002) and increased siltation, resulting in an impoverishment in benthic species richness, abundance and biomass as mentioned above.

In a similar way, fine inorganic particles from glacier abrasion in Potter Cove (South Shetland Is., Antarctic Peninsula) favour ascidians, pennatulids, large Laternula elliptica and cumaceans and suppress sponges, small bivalves and polychaetes, whose filtering apparatus may be clogged (Kowalke 
et al., 2001; Kowalke and Abele, 1998; Tatián et al., 1998; Sahade et al., 1998). On hard bottoms the foliage of macroalgae, particularly of large kelp Himanthothallus, may act as a disturbant in addition to ice effects; ascidians dominate here, too, due to their high competitive abilities (Sahade et al., 1998).

The effects of large-scale disruption as occurred with the Larsen ice shelf (east coast of Antarctic Peninsula; Domack et al., 2005) has not yet been studied in macrobenthic communities. However, a project has been developed (Gutt, unpubl.) and from all we know, remarkable changes have to be expected (Arntz, 1998).

Whereas information on ice disturbance is somewhat stagnant at lower latitudes, it has improved substantially in the high Antarctic. Gutt and Starmans (2001) analysed abt. $25 \mathrm{~km}^{2}$ of video transects and UW photos on the Weddell Sea shelf and found signs of iceberg disturbance on $42-70 \%$ of the bottoms. Fairly recent iceberg scours of different age cover about $7 \%$ of the Weddell Sea shelf, but in iceberg resting sites like Austasen the coverage is much higher, and only $20 \%$ are unaffected (Arntz and Gutt, 1999, Summary). Near Kapp Norvegia, icebergs cover a considerable part of the shelf between 200 and $400 \mathrm{~m}$ depth; iceberg resting sites can extend over areas between 40 and $170 \mathrm{~km}^{2}$ (Knust et al., 2003). Based on survey data and growth studies of the pioneer species Cellaria incula (Brey et al., 1999), Gutt (2001) concluded that each square metre at depths $<500 \mathrm{~m}$ on the Antarctic shelf is disturbed by icebergs every 340 yr on average.

Despite its immediate destructive effects, it is evident now that iceberg scouring enhances diversity whereas glaciers cause faunal impoverishment (Gutt, 2001). Iceberg disturbance destroys the fauna at small scale, but the large variety of successional patterns increases diversity at medium (regional) scales (Gutt et al., 1998; Gutt, 2001; Gutt and Piepenburg, 2003; Fig. 8).

Cluster analysis of macrofauna clearly separated fresh scours, old scours and undisturbed areas (Knust et al., 2003). Fresh scour marks were characterized by lowest total abundance and low biomass. Dominant taxa in fresh scours were polychaetes and crustaceans followed by juvenile brittle stars; tunicates and sponges were absent. In old scour marks a dominance of echinoderms, polychaetes, and brittle stars was found as well as of bryozoans and smaller sponges (both increasing), and in undisturbed areas a high dominace of sponges and echinoderms with bryozoans (however, the latter less dominant than in old scours).

A detailed taxonomic approach using polychaetes (Gerdes et al., 2003) showed highest densi-

\section{alpha} local scale, $20 \mathrm{~m}^{2}$

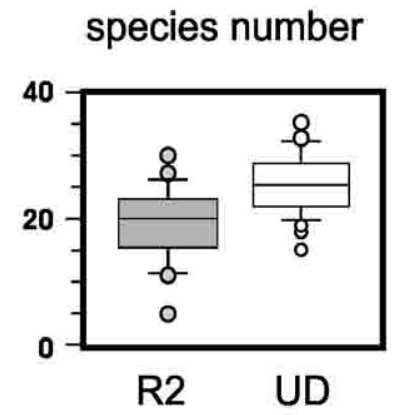

gamma regional scale, $200 \mathrm{~km}$ coastline

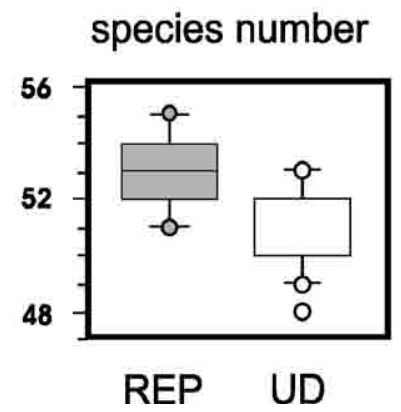

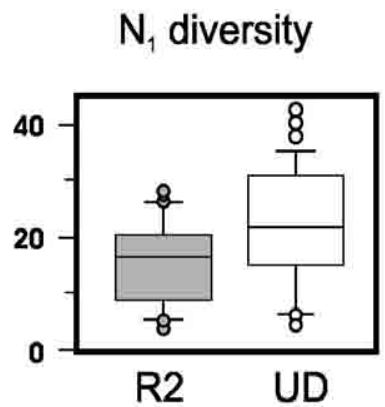
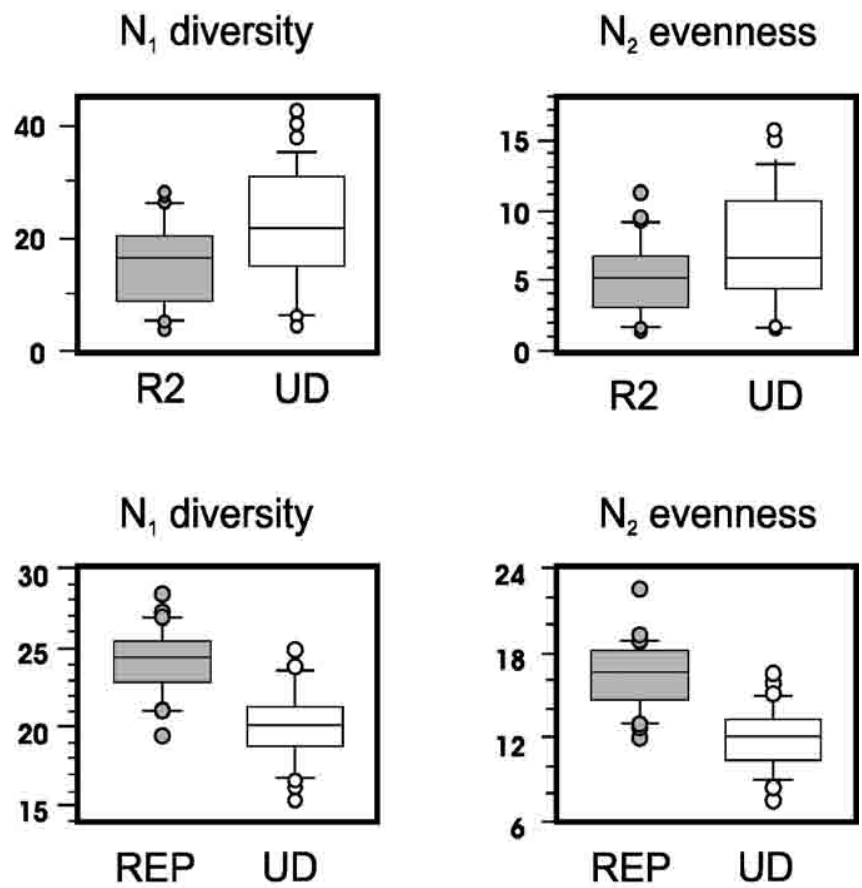

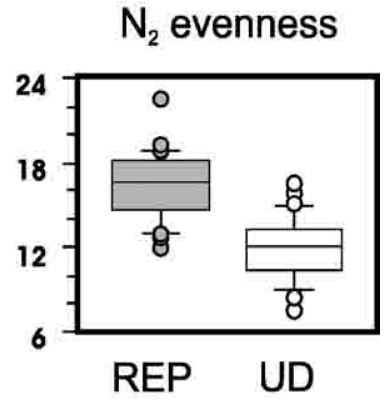

FIG. 8. - Dependence of Antarctic diversity and evenness on spatial scales. On larger scales values increase in areas subject to iceberg scour due to the simultaneous presence of different successional stages. REP, R2 are recolonisation stages, UD undisturbed areas. From Gutt and Piepenburg (2003), redrawn. 

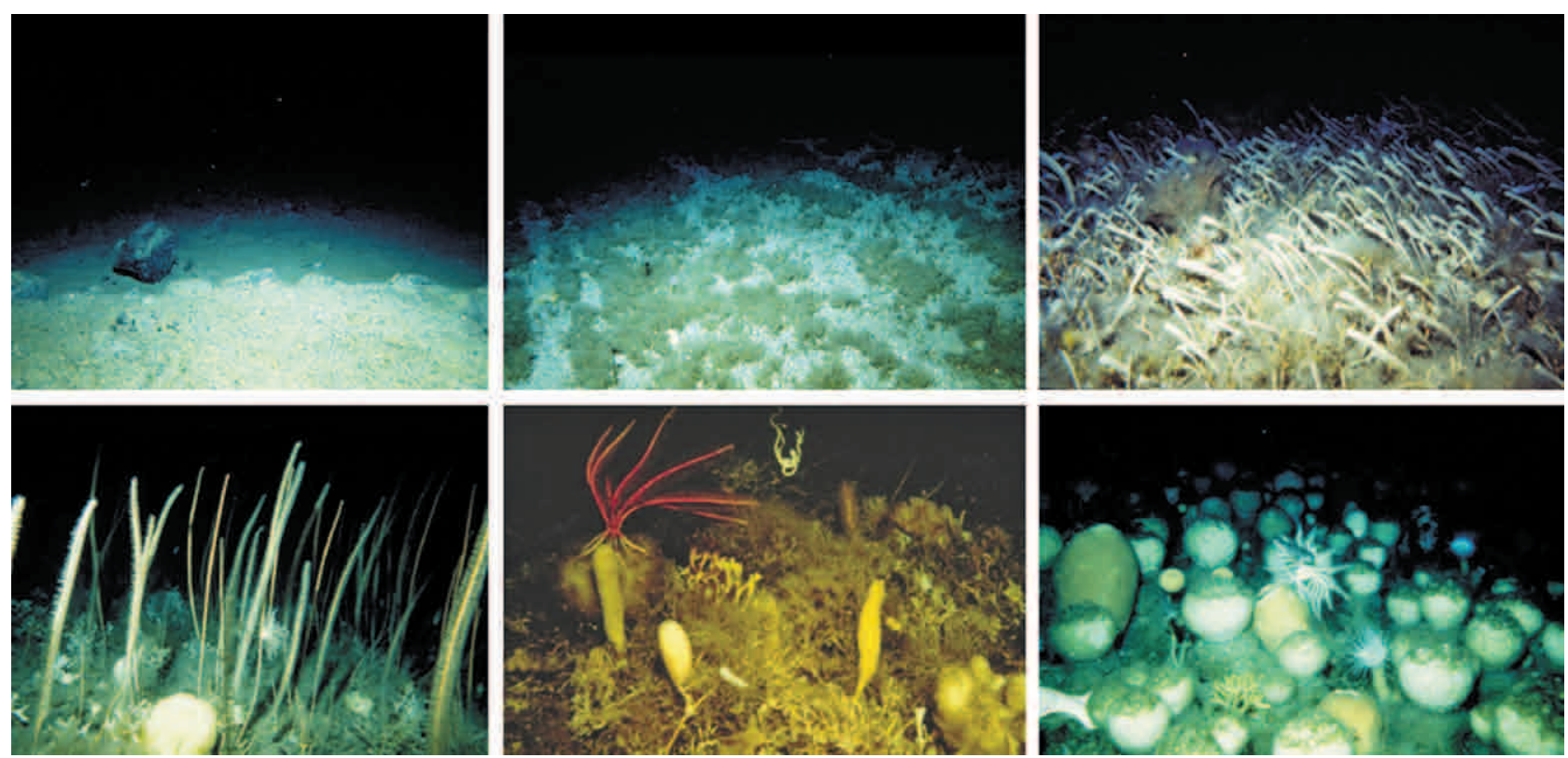

FIG. 9. - Hypothetical succession after iceberg impact, from the devastated stage via pioneer stages to a fully developed epibenthic assemblage (southeastern Weddell Sea). There are alternative successional stages, but the exact time scale for the process of recolonisation is still unknown. (Photos: WG J. Gutt)

ties and habitat species richness in undisturbed areas, followed by old and young scours. The polychaete fauna was found to be impoverished in iceberg scours also in terms of the variety of feeding types and life styles.

Various early colonisers were identified: colonial ascidians (Synoicium), bryozoans (Cellaria, Cellarinella), the stalked sponge Stylocordyla, the solitary ascidian Molgula, the gorgonians Primnoisis, Ainigmaptilon and the polychaete Pista (Gutt et al., 1996; Arntz and Gutt, 1999, Summary Review; Bader, 2002). Stylocordyla borealis might be able to regenerate lost bodies if only the stem is left after a disturbance (Gatti, 2001). The stem contains only $20 \%$ of the total organic carbon of an individual. Other sponges produce buds under certain circumstances (Teixidó et al., in press). Both may be mechanisms to speed up recolonisation.

Megafauna from UW camera and video transects produced data with a higher resolution and, consequently, better distinction between different successional stages (Fig. 9) in the Antarctic (e.g. Gutt and Starmans, 1998, 2001; Starmans et al., 1999; Gutt and Piepenburg, 2003) and Magellan benthos (Gutt et al., 1999). Teixidó et al. (2002, 2004) applied methods of landscape ecology to analyse quantitatively spatial patterns in Antarctic megabenthic communities. Using standardized UW camera photos and landscape indices, spatial patterns were studied in an undisturbed benthic assemblage and through successional stages after iceberg disturbance. The results describe a gradient from early stages of recovery with low coverage, low complexity of patch shape, small patch size, low diversity, and patches poorly interspersed to later stages with higher values of these indices. There was no fixed sequence of pioneer species during this process, but the pioneers occurred in high (sometimes almost monospecific) densities and were patchily distributed. Dominant taxa in this successional phase were demosponges, gorgonians, bryozoans, polychaetes and ascidians. Some species of these major taxa exhibit much faster growth than is normally found in Antarctic waters (e.g. Brey et al., 1999; Kowalke et al., 2001). In an advanced stage of succession it was mainly bryozoans that dominated. In this stage the highest values were encountered of cover area and density. The climax stage was characterized by large and presumably very old demosponges and siliceous sponges as well as (other) bryozoans, ascidians and gorgonians, whose cover area and density was, however, reduced as compared with the previous stage. Different growth forms dominated the various successional stages, and life strategies (presence of pelagic larvae or drift stages, brooding, budding) seemingly determined to a certain extent the course of succession. The most successful pioneers were characterized by tree-shaped growth form, relatively fast growth, and low to intermediate dispersal capacity of their larvae (Teixidó et al., 2004). 
In view of the inherent difficulties to collect material and data regularly in the Antarctic (less so in the Magellan region), consistent long-term data series are rare. In this case spatially explicit modelling of processes shaping diversity patterns may be a useful approach to answer questions on ecosystem functioning. A first attempt is presently being made to simulate benthic succession after iceberg scouring, emphasizing the role of biological characteristics such as dispersal, growth and recruitment, interactions between species inhabiting different successional stages and basic environmental parameters (Johst et al., unpubl.; Potthoff, pers. comm.). The first results from this modelling suggest that former assumptions as to the extremely low pace of Antarctic community development may have to be reconsidered, and that the dispersal mode plays a very important role.

Hill's diversity concept (Hill, 1973) of a gradient with increasing weight of equitability and decreasing species numbers was used as a gradient of measures with increasing sensitivity to any kind of impact or environmental change, and applied to Antarctic benthos data to check the "intermediate disturbance hypothesis" (Gutt and Piepenburg, 2003). The authors did not find a decrease of diversity due to increasing competitive displacement at a late stage of succession following devastation of the community by grounding icebergs. However, adding to this concept landscape measures describing spatial patterns by computing areas covered by organisms and their circumference, an effect of competition seemed to occur (Teixidó et al., 2002).

Other compartments in the high Antarctic benthal such as meiofauna and demersal fish are also affected by iceberg scouring (Lee et al., 2001 a,b; Brenner et al., 2001; Mintenbeck, 2001; Knust et al., 2003). Through area fragmentation and continuous creation of free spaces, natural disturbance thus might be a process favouring speciation, and this process might be more active under present conditions in the Antarctic than in the Magellan region.

Anthropogenic disturbance affecting assemblages at the seafloor is another field, where comparisons on a latitudinal gradient would provide interesting results on benthic resilience.

Lenihan and Oliver (1995) investigated the structure of benthic communities around McMurdo station and the changes due to anthropogenic contamination as compared to two large-scale natural disturbances, anchor ice uplift and iceberg scour. The effects were similar; however contamination had a much more long lasting effect, and recovery from it was expected to be much slower. Human impact and the development of benthic communities responding to sewage, also at Mc Murdo, are studied by Conlan et al. (2003). A former sewage outlet, which ended at the shoreline, was replaced in 1991 by another outlet at $18 \mathrm{~m}$ depth, $56 \mathrm{~m}$ distant from shore; from 2003 the sewage has been treated. Presently a lot of contamination continues, also due to dumping of chemical waste in a nearby bay. Recovery velocity is followed under polar conditions after sewage abatement.

Human impact is also investigated in benthic communities at Casey (Stark and Riddle, 2003). Differences between impacted and reference stations around Casey Station are probably due to heavy metals and hydrocarbons. Field experiments have been conducted to demonstrate a causal relationship, showing that different assemblages developed at polluted and non-polluted sites.

\section{Deficiencies and perspectives}

Even though considerable progress has been made since the first IBMANT Conference in Punta Arenas, numerous gaps still remain in our knowledge, some of which were already identified during IBMANT I:

- Major tectonic, oceanographic and climatological events that supposedly shaped Antarctic biotic evolution should be identified and related to the molecular genetic results. Presently neither the former nor the latter approach provide a firm base to arrive at comprehensive conclusions across disciplines.

- Relations and interactions of the Antarctic with surrounding areas other than the Magellan region remain obscure; differences in similarity level with Antarctic biota between South America and Australia should be studied as an indirect measure of continental drift related evolutionary changes.

- Concerning almost all subjects dealt with in this review, research in the Magellan region must be strengthened. Presently the state of knowledge is much better for the Antarctic than for the "Cono Sur".

- More "circumantarctic" species should be studied using molecular techniques to detect cryptic species. For biodiversity purposes, traditional taxonomy remains important as most larger taxa (e.g., polychaetes) require identification to species level. 
- Accessible fossil evidence is restricted to few sites in the Antarctic (Taviani et al., 1998; Crame, 1999; Malumian and Olivero, 2005), and the record is only slowly improving.

- There is evidence for a convergent evolution of high Antarctic sessile suspension feeders to similar morphotypes as in the Cretaceous or earlier, however it requires further study of the responsible ecofactors.

- The Scotia Arc and Bouvet Island (see Arntz, in press) are clearly undersampled, considering their potential significance as transitory areas between the Magellan region, the tip of the Antarctic Peninsula and the high Antarctic.

- Further shallow areas should be studied in those high Antarctic regions where they are very scarce, to enable comparisons with shallow-water biota inside and outside the Antarctic and to elucidate the origin of their fauna.

- Areas under permanent pack ice cover and areas recently disclosed by ice shelf calving should be studied and compared with polynya areas to identify the consequences of extreme oligotrophy, and to follow recolonisation.

- Perturbation effects such as those from iceberg scour should be inflicted experimentally, and should include modelling approaches, to enable verification of successional processes and their duration, which will allow an improved judgement on ecosystem vulnerability and recoverability.

- Recolonisation experiments on soft and hard substrates, both short- and long term, should provide further data on the pace of succession and resilience under polar conditions.

- Influences from climate oscillations such as ENSO or the Antarctic Circumpolar Wave (White and Peterson, 1996) have been suspected by various authors but need more attention.

- More data on life cycles, reproductive strategies and physiological adaptations of benthic key species are badly needed.

- Meroplanktonic larvae, in particular, deserve an increased research input in deeper shelf areas.

- Close cooperation with physiologists should be enhanced, because it may lead to causal explanation of empirical ecological finds.

Similar to the EASIZ programme (Arntz and Clarke, 2002), which finished in 2004, the recently designed SCAR programme EBA (Evolution and Biodiversity in the Antarctic) provides an excellent thematic background for the continuation of IBMANT research on the interaction between the
Antarctic and other remnants of Gondwana. Furthermore, cooperation with ANDEEP may enable us to check those potential links via the deep sea, which have emerged from research on the Antarctic and Magellan shelves.

\section{ACKNOWLEDGEMENTS}

Many colleagues improved former versions or individual aspects of this paper with comments, corrections and additional information. We would like to thank, in particular, Hugo Arancibia, David Barnes, Tom Brey, Christoph Held, Katrin Linse, Erika Mutschke, Carlos Ríos and Christian Wiencke. Andrea Bleyer and Werner Mensing provided substantial technical assistance. The competence and helpfulness of the captains, officers and crews of RVs "Polarstern", "Victor Hensen" and "Vidal Gormaz" during long Antarctic and Magellan cruises under difficult conditions is much appreciated.

\section{REFERENCES}

Abele, D., C. Wiencke, and H.O. Pörtner. - 1998. Oxidative stress and temperature acclimation in Antarctic shallow water molluscs. Ber. Polarforsch., 299: 237-242.

Anger, K., S. Thatje, G. Lovrich and J. Calcagno. - 2003. Larval and early juvenile development of Paralomis granulosa reared at different temperatures: tolerance of cold and food limitation in a lithodid crab from high latitudes. Mar. Ecol. Progr. Ser., 253: 243-251.

Anger, K., G.A. Lovrich, S. Thatje and J.A. Calcagno. - 2004. Larval and early juvenile development of Lithodes santolla (Decapoda: Anomura: Lithodidae) reared at different temperatures in the laboratory. J. Exp. Mar. Biol. Ecol., 306: 217-230.

Arana, P.M. and M.A. Retamal. - 1999. Nueva distribución de Paralomis birsteini Macpherson, 1988 en aguas antárticas (Anomura, Lithodidae, Lithodinae). Invest. Mar., 27: 101-110.

Arnaud, P.M. - 1970. Frequency and ecological significance of necrophagy among the benthic species of Antarctic coastal waters. In: M.W. Holdgate (ed.), Antarctic Ecology, Vol. 1, 259-267. Academic Press, London.

Arnaud, P.M., C.M. López, I. Olaso, F. Ramil, A.A. Ramos-Esplá and A. Ramos. - 1998. Semi-quantitative study of macrobenthic fauna in the region of the South Shetland Islands and the Antarctic Peninsula. Polar Biol., 19: 160-166.

Arntz, W.E. - 1997. Investigación antártica en biología marina: situación actual, proyectos internacionales y perspectivas. Bol. R. Soc. Esp. Hist. Nat., 93 (1-4): 13-44.

Arntz, W.E. - 1998. Marine ecology in Antarctica and its connections to "global change". In: M. Piccazzo (ed.), Atti del $12^{\circ}$ Congresso dell'Associazione Italiana di Oceanologia e Limnologia, Vol. II: 3-27.

Arntz, W.E. (ed.) - (in press). Macrobenthos studies at Bouvet Island. Polar Biol., Special Issue.

Arntz, W.E. and T. Brey (eds.). - 2003. The Expedition ANTARKTIS XIX/5 (LAMPOS) of RV „Polarstern“ in 2002. Ber. Polaru. Meeresforsch., 462.

Arntz, W.E. and T. Brey (eds.). - 2005. The Expedition ANTARKTIS XXI/2 (BENDEX) of RV „Polarstern“" in 2003/2004. Ber. Polar- $u$. Meeresforsch., 503: 149 pp.

Arntz, W.E. and A. Clarke (eds.). - 2002. Ecological studies in the 
Antarctic Sea Ice Zone. Results of EASIZ midterm symposium, pp. 1-277. Springer-Verlag, Heidelberg

Arntz, W.E. and Gili, J.M. - 2001. A case for tolerance in marine ecology: let us not put out the baby with the bathwater. In: J.M.Gili, J.L. Pretus and T.T. Packard (eds.), A Marine Science Odyssey into the 21st Century. Sci. Mar., 65(Suppl. 2): 283-299.

Arntz, W.E. and M. Gorny. - 1991. Shrimp (Decapoda, Natantia) occurrence in the eastern Weddell Sea. Polar Biol., 11: 169177.

Arntz, W.E. and M. Gorny (eds.). - 1996. Cruise Report of the Joint Chilean-German-Italian Magellan „Victor Hensen“ Campaign in 1994. Ber. Polarforsch., 190: 1-113.

Arntz, W.E. and J. Gutt (eds.). - 1997. The Expedition ANTARKTIS XIII/3 (EASIZ I) of „Polarstern“ to the eastern Weddell Sea in 1996. Ber. Polarforsch., 249: $148 \mathrm{pp}$.

Arntz, W.E. and J. Gutt (eds.). - 1999. The Expedition ANTARKTIS XV/3 (EASIZ II) of RV „Polarstern“ in 1998. Ber. Polarforsch., 301: $229 \mathrm{pp}$.

Arntz, W.E. and C. Ríos (eds.). - 1999. Magellan-Antarctic: Ecosystems that drifted apart. Sci. Mar., 63(Suppl. 1): 518 pp.

Arntz, W.E. and S. Thatje. - 2002. Latitudinal gradients in ecological parameters of decapod crustaceans. Arctic Research Journal, 1: 34-35.

Arntz, W.E., T. Brey, J. Tarazona and A. Robles. - 1987. Changes in the structure of a shallow sandy-beach community in Peru during an El Niño event. S. Afr. J. Mar. Sci., 5: 645-658.

Arntz, W.E., T. Brey, D. Gerdes, M. Gorny, J. Gutt, S. Hain and M. Klages. - 1992. Patterns of life history and population dynamics of benthic invertebrates under the high Antarctic conditions of the Weddell Sea. In: G. Colombo, I. Ferrari, V. U. Ceccherelli and R. Rossi (eds.), Marine Eutrophication and Population Dynamics), pp. 221-230. Olsen and Olsen, Fredensborg.

Arntz, W.E., T. Brey and V.A. Gallardo. - 1994. Antarctic zoobenthos. Oceanogr. Mar. Biol.: an Annual Review: 32: 241-304.

Arntz, W.E., J. Gutt and M. Klages. - 1997. Antarctic marine biodiversity: an overview. In: B. Battaglia, J. Valencia and D. Walton (eds.), Antarctic communities, pp. 3-14. Cambridge Univ. Press, Cambridge

Arntz, W.E., M. Gorny, R. Soto, M.A. Lardies, M. Retamal and I.S. Wehrtmann. - 1999. Species composition and distribution of decapod crustaceans in the waters off Patagonia and Tierra del Fuego, South America. Sci. Mar., 63(Suppl 1): 303-314.

Aronson, R.B. and D.B. Blake. - 2001. Global climate change and the origin of modern benthic communities in Antarctica. Amer. Zool., 41: 27-39.

Bader, B. - 2002. Bryozoan communities in the Weddell Sea, Antarctica: A first overview. Bryozoan Studies 2001, In: P. Wyse-Jackson, C.J. Buttler and M.E. Spencer Jones (eds.), Bryozoan Studies 2001, pp. 1-6, Balkema Publishers (Lisse).

Baeza, J.A. and M. Fernández. - 2002. Active brood care in Cancer setosus (Crustacea: Decapoda): the relationship between female behaviour, embryo oxygen consumption and the cost of brooding. Funct. Ecol., 16: 241-251.

Bargelloni, L., S. Marcato, L. Zane and T. Patarnello. - 2000. Mitochondrial phylogeny of notothenioids: A molecular approach to Antarctic fish evolution and biogeography. Syst. Biol., 49: 114-129.

Barker, P.F. and J. Burrell. - 1977. The opening of Drake Passage. Marine Geol., 25: 15-34.

Barker, P.F. and E. Thomas. - 2004. Origin, signature and palaeoclimatic influence of the Antarctic Circumpolar Current. EarthScience Reviews, 66: 143-162.

Barnes, D.K.A. - 2002. Invasions by marine life on plastic debris. Nature, 416: 808-809.

Barnes, D.K.A. - 2005. Changing chain: past, present and future of the Scotia Arc's shallow benthic communities. In: W.E. Arntz, G.A. Lovrich and S. Thatje (eds.), The Magellan-Antarctic connection: links and frontiers at high southern latitudes. Sci. Mar., 69 (Suppl. 2): 65-89.

Barnes, D.K.A. and R. Arnold. - 2001. Competition, sub-lethal mortality and diversity on Southern Ocean coastal rock communities. Polar Biol., 24: 447-454.

Barnes, D.K.A. and A. Clarke. - 1995. Seasonality of feeding activity in Antarctic suspension feeders. Polar Biol., 15: 335-340.

Barnes, D.K.A. and A. Clarke. - 1998. The ecology of an assemblage dominant: the encrusting bryozoan Fenestrulina rugula. Invertebr. Biol., 117: 331-340.

Barnes, D.K.A. and S. De Grave. - 2001. Ecological biogeography of southern polar encrusting faunas. J. Biogeogr., 28: 359-365.

Barrera-Oro, E. - 2002. The role of fish in the Antarctic marine food web: differences between inshore and offshore waters in the southern Scotia Arc and west Antarctic Peninsula. Antarct. Sci., 14 (4): 239-309.

Barrera-Oro, E.R. and R.J. Casaux. - 1998. Analysis of the diet of Champsocephalus gunnari at South Georgia in late summer from 1994 to 1997. CCAMLR Science, 5: 43-52.

Benn, D. and C. Clapperton. - 2000. Glacial sediment-landform associations and paleoclimate during the last glaciation, Strait of Magellan, Chile. Quaternary Res., 54: 13-23.

Berkman, P.A., T.R. Waller and S.P. Alexander. - 1991. Unprotected larval development in the Antarctic scallop Adamussium colbecki (Mollusca: Bivalvia: Pectinidae). Ant. Sci., 3 (2): 151-157.

Berkman, P.A., R. Cattaneo-Vietti, M. Chiantore, C. HowardWilliams, V. Cummings and R. Kvitek. - 2005. Marine research in the Latitudinal Gradient Project along Victoria Land, Antarctica. In: W.E. Arntz, G.A. Lovrich and S. Thatje (eds.), The Magellan-Antarctic connection: links and frontiers at high southern latitudes. Sci. Mar., 69(Suppl. 2): 57-63.

Beu, A.G., M. Griffin and P.A. Maxwell. - 1997. Opening of Drake Passage gateway and late Miocene to Pleistocene cooling reflected in Southern Ocean molluscan dispersal: evidence from New Zealand and Argentina. Tectonophysics, 281, No. 12: 83-97.

Bischof, K., D. Hanelt, H. Tüg, U. Karsten, P.E.M. Brouwer and C. Wiencke. - 1998. Acclimation of brown algal photosynthesis to ultraviolet radiation in Arctic coastal waters (Spitsbergen, Norway), Polar Biol., 20: 388-395.

Bischoff-Bäsmann, B. and C. Wiencke. - 1996. Temperature requirements for growth and survival of Antarctic Rhodophyta. J. Phycol., 32: 525-535.

Blazewicz, M. and K. Jazdzewski. - 1996. A contribution to the knowledge of Tanaidacea (Crustacea, Malacostraca) of Admiralty Bay, King George Island, Antarctic. Polish Polar Research, 17 (3-4): 213-220.

Boschi, E.E. - 2000. Species of decapod crustaceans and their distribution in the American marine zoogeographic provinces. Rev. Invest. Desarr. Pesq., 13: 1-136.

Brandt, A. - 1991. Zur Besiedlungsgeschichte des antarktischen Schelfes am Beispiel der Isopoda (Crustacea, Malacostraca). Ber. Polarforsch, 98: 1-240.

Brandt, A. - 2000. Hypotheses on Southern Ocean peracarid evolution and radiation (Crustacea, Malacostraca). Antarct. Sci., 12: 269-275.

Brandt, A. and B. Hilbig (eds.). - 2004. ANDEEP (Antarctic Benthic Deep-Sea Biodiversity): Colonization History and Recent Community Patterns - a Tribute to Howard L. Sanders. DeepSea Res. II, 51: 1457-1919.

Brandt, A. and G. Poore - 2003. Higher classification of the flabelliferan and related Isopoda based on a reappraisal of relationships. J. Invert. Systematics, 17: 893-923.

Brandt, A., K. Linse and U. Weber. - 1997. Abundance and diversity of peracarid taxa (Crustacea, Malacostraca) along a transect through the Beagle Channel, Patagonia. Polar Biol., 18: 83-90.

Brandt, A., K. Linse and U. Mühlenhardt-Siegel. - 1999. Biogeography of Crustacea and Mollusca of the Magellan and Antarctic regions. Sci. Mar., 63(Suppl. 1): 383-389.

Brante, A., M. Fernández, L. Eckerle, F. Mark, H.O. Pörtner and W. Arntz. - 2003. Reproductive investment in the crab Cancer setosus along a latitudinal cline: egg production, embryo losses and embryo ventilation. Mar. Ecol. Progr. Ser., 251: 221-232.

Brenner, M., B.H. Buck, S. Cordes, L. Dietrich, U. Jacob, K. Mintenbeck, A. Schröder, T. Brey, R. Knust and W. Arntz. 2001. The role of iceberg scours in niche separation within the Antarctic fish genus Trematomus. Polar Biol., 24: 502-507.

Brey, T. and D. Gerdes. - 1999. Benthic community productivity in the Magellan region and in the Weddell Sea. Sci. Mar., 63 (Suppl. 1): 145-148.

Brey, T., D. Gerdes, J. Gutt, A. Mackensen and A. Starmans. 1999. Growth and age of Antarctic bryozoan Cellaria incula on the Weddell Sea Shelf. Antarct. Sci., 11(4): 408-414.

Briand, F. and J.E. Cohen. - 1987. Environmental correlates of food chain length. Science, 238: 956-960.

Brodte, E. - 2001. Growth and fecundity of two eelpout species Zoarces viviparus (Linne) and Pachycara brachycephalum (Pappenheim) from different climatic regions. Diploma thesis, 
Univ. Bremen.

Bruns, T. - 1992. Experimentelle Untersuchungen zur Larvalentwicklung antarktischer Garnelen (Decapoda, Natantia). Diploma thesis, Univ. Osnabrück.

Cantone, G., A. Castelli and M.C. Gambi. - 2000. Benthic polychaetes off Terra Nova Bay and Ross Sea: species composition, biogeography, and ecological role. In: (F.M. Faranda, L. Guglielmo and A. Ianora (eds.), Ross Sea Ecology, pp. 551561. Springer-Verlag.

Cattaneo-Vietti , R., M. Chiantore, M.C. Gambi, G. Albertelli, M. Cormaci and I. Di Geronimo. - 2000a. Spatial and vertical distribution of benthic littoral communities in Terra Nova Bay. In: F.M. Faranda, L. Guglielmo and A. Ianora (eds.), Ross Sea Ecology, pp. 503-514. Springer-Verlag.

Cattaneo-Vietti, R., G. Bavestrello, C. Cerrano, E. Gaino, L. Mazzella, M. Pansini and M. Sarà. - 2000b. The Role of Sponges in the Terra Nova Bay Ecosystem. In: Ross Sea Ecology, pp. 539-549. Springer-Verlag.

CCAMLR (Commission for the Conservation of Antarctic Marine Living Resources). - 1994. Report of the thirteenth meeting of the Commission. Hobart.

CCAMLR. - 1996. Report of the fifteenth meeting of the Commission. Crab resources: 43-45.

CCAMLR. - 2005. See http://www.ccamlr.org/

Cerrano, C., S. Puce, M. Chiantore and G. Bavestrello. - 2000. Unusual trophic strategies of Hydractinia angusta (Cnidaria, Hydrozoa) from Terra Nova Bay, Antarctica. Polar Biol., 23: 488-494.

Chapelle, G. and L.S. Peck. - 1999. Polar gigantism dictated by oxygen availability. Nature, 399: $144 \mathrm{f}$

Chen, L.B., A.L. DeVries and C.H.C. Cheng. - 1997. Evolution of antifreeze glycoprotein gene from a trypsinogene in Antarctic notothenioid fish. P. Natl. Acad. Sci. USA., 94: 3811-3816.

Chiantore, M., R. Cattaneo-Vietti, P. Povero and G. Albertelli. 2000. The population structure and ecology of the Antarctic scallop Adamussium colbecki in Terra Nova Bay. In: F.M. Faranda, L. Guglielmo and A. Ianora (eds.), Ross Sea Ecology, pp. 563-573. Springer, Berlin.

Chiantore, M., R. Cattaneo-Vietti, P. Berkman, M. Nigro, M. Vacchi, S. Schiaparelli and G. Albertelli. - 2001. Antarctic scallop (Adamussium colbecki) spatial population variability along the Victoria Land coast, Antarctica. Polar Biol., 24: 139-143.

Chiantore, M., R. Cattaneo-Vietti, O. Heilmayer. - 2003. Antarctic scallop (Adamussium colbecki) annual growth rate at Terra Nova Bay, Polar Biol., 26 (6): 416-419.

Clapperton, C.M. - 1993a. Glacier readvances in the Andes at 12500-10000 yr BP: implications for mechanism of late-glacial climatic change. J. Quaternary Sci, 8: 197-215.

Clapperton, C.M. - 1993b. Nature of environmental changes in South America at the last glacial maximum. Palaeogeogr., Palaeoclimat., Palaeoecol., 101: 189-208.

Clapperton, C., D. Sugden, D. Kaufman and R. McCulloch. - 1995. The last glaciation in the central Magellan Strait, southernmost Chile. Quaternary Res., 44: 133-148.

Clarke, A. - 1992. Reproduction in the cold: Thorson revisited. Invertebr. Reprod. Dev., 22: 175-184.

Clarke, A. - 2003a. Evolution, adaptation and diversity: global ecology in an Antarctic context. In: A.H.L. Huiskes, W.W.C. Gieskes, J. Rozema, R.M.L. Schorno, S.M. van der Vies, and W.J. Wolff (eds.), Antarctic biology in a global context, pp. 317. Backhuys Publishers, Leiden.

Clarke, A. - 2003b. Costs and consequences of evolutionary temperature adaptation. Trends Ecol. Evol., 18: 573-581.

Clarke, A. and J.A. Crame. - 1989. The origin of the Southern Ocean marine fauna. In: J.A. Crame (ed.), Origins and evolution of the Antarctic biota, pp. 253-268. The Geol. Soc. Spec. Publ., 47. London.

Clarke, A. and J.A. Crame. - 1997. Diversity, latitude and time: patterns in the shallow sea. In: R.F.G. Ormond, J.D. Gage and M.V. Angel, Marine biodiversity: patterns and processes, $\mathrm{pp.}$ 122-147. Cambridge Univ. Press, Cambridge.

Clarke, A. and N.M. Johnston. - 2003. Antarctic marine benthic diversity. Oceanogr. Mar. Biol. Ann. Rev., 41: 47-114.

Clarke, A. and R.J.G. Leakey. - 1996. The seasonal cycle of phytoplankton, macronutrients, and the microbial community in a nearshore Antarctic marine ecosystem. Limnol. Oceanogr., 41: 1281-1294.

Cledón, M. - 2004. Reproductive biology and ecology of Ade- lomelon brasiliana (Mollusca: Gastropoda) off Buenos Aires, Argentina. Ph.D thesis, FB 2 Biology/Chemistry Univ. Bremen, $105 \mathrm{pp}$

Coleman, C.O. - 1990. Two new Antarctic species of the genus Epimeria (Crustacea: Amphipoda: Paramphithoidae), with descriptions of juveniles. J. R. Soc. N.Z., 2: 151-178.

Collins, M.A., C. Yau, F. Guillfoyle, P. Bagley, I. Everson, I.G. Pirede and D. Agnew. - 2002. Assessment of stone crab (Lithodidae) density on the South Georgia slope using baited video cameras. ICES J. Mar. Sci., 59: 1-9.

Collins, M.A., M. Belchier and I. Everson. - 2003. Why the fuss about toothfish? Biologist, 50: 117-119.

Colwell, R.K. - 1997. Estimates: Statistical estimation of species richness and shared species from samples, version 5. User's Guide and application published at http://viceroy.eeb.uconn.edu/estimates.

Comoglio, L.I. and O.A. Amin. - 1999. Feeding habits of the false southern king crab Paralomis granulosa (Lithodidae) in the Beagle Channel, Tierra del Fuego, Argentina. Sci. Mar., 63 (Suppl. 1): 361-366.

Conlan, K.E., S.L. Kim, H.S. Lenihan and J.S. Oliver. - 2003. Benthic community changes at McMurdo Station: a response to sewage abatement. In: A.H.L. Huiskes, W.W.C. Gieskes, J. Rozema, R.M.L. Schorno, S.M. van der Vies and W.J. Wolff (eds.), Antarctic biology in a global context, pp. 264-270. Backhuys Publishers, Leiden.

Convey, P., D.K.A. Barnes and A. Morton. - 2002. Artefact accumulation on Antarctic oceanic island shores. Polar Biol., 25: 612-617.

Cornejo, S. - 1996. Reporte preliminar de macroalgas presentes en Bahía Laredo, Estrecho de Magallanes. Ans. Inst. Pat., Ser. Cs. Nat., 24: 87-95.

Crame, J.A. - 1997. An evolutionary framework for the polar regions. J. Biogeogr., 24: 1-9.

Crame, J.A. - 1999. An evolutionary perspective on marine faunal connections between southernmost South America and Antarctica. In: W.E. Arntz and C. Ríos (eds.), Magellan-Antarctic, Ecosystems that Drifted Apart. Sci. Mar., 63 (Suppl.1): 1-14.

Crame, J.A. - 2000 a. Evolution of taxonomic diversity gradients in the marine realm: evidence from the composition of recent bivalve faunas. Paleobiology, 26: 188-214.

Crame, J.A. -2000 b. The nature and origin of taxonomic diversity gradients in marine bivalves. In: E. Harper et al. (eds.), The Evolutionary Biology of the Bivalvia, pp. 347-360. The Geol. Soc., London.

Cranmer, T.L., H.A. Ruhl, R.J. Baldwin and R.S. Kaufmann. 2003. Spatial and temporal variation of epibenthic megafauna in Port Foster, Deception Island. Deep-Sea Res. II, 50: 18211842.

Cripps, G.C and A. Clarke. - 1998. Seasonal variation in the biochemical composition of particulate material collected by sediment traps at Signy Island, Antarctica. Polar Biol., 20: 414-423.

Dauby, P., Y. Scailteur and C. De Broyer. - 2001a. Trophic diversity within the eastern Weddell Sea amphipod community. Hydrobiologia, 443: 69-86.

Dauby, P., Y. Scailteur, G. Chapelle and C. De Broyer. - 2001b. Potential impact of the main benthic amphipods on the eastern Weddell Sea shelf ecosystem (Antarctica). Polar Biol. 24: 45-50.

Dauby, P., F. Nyssen and C. De Broyer. - 2003. Amphipods as food sources for higher trophic levels in the Southern Ocean: a synthesis. In: A.H.L. Huiskes, W.W.C. Gieskes, J. Rozema, R.M.L. Schorno, S.M. van der Vies, and W.J. Wolff (eds.), Proc. SCAR Biol. Symp. Amsterdam, Antarctic biology in a global context, pp. 129-134. Backhuys Publishers, Leiden.

David, B., T. Choné, A. Festeau, R. Mooi and C. De Ridder. 2005. Biodiversity of Antarctic echinoids: a comprehensive and interactive data base. In: W.E. Arntz, G.A. Lovrich and S. Thatje (eds.), The Magellan-Antarctic connection: links and frontiers at high southern latitudes. Sci. Mar., 69(Suppl. 2): 201-203.

Dávila, P., D. Figueroa and E. Müller. - 2002. Freshwater input into the coastal ocean and its relation with the salinity distribution off austral Chile $\left(35-55^{\circ} \mathrm{S}\right)$. Cont. Shelf Res., 223: 521-534.

Dayton, P.K. - 1990. Polar benthos. In: W.O. Smith Jr. (ed.), Polar Oceanography, Part B: Chemistry, Biology, and Geology, pp. 631-685. Academic Press, San Diego.

De Broyer, C., J.-H. Hecq and S. Vanhove. - 2001a. Life under the 
ice: biodiversity of the Southern Ocean. Proc. Belgica Centennial Symp. 1998, VUB Brussels: 271-286.

De Broyer, C., Y. Scailteur, G. Chapelle and M. Rauschert. - 2001b. Diversity of epibenthic habitats of gammaridean amphipods in the Eastern Weddell Sea. Polar Biol., 24: 744-753.

De Broyer, C., K. Jazdzewski and P. Dauby. - 2003. Biodiversity patterns in the Southern Ocean: lessons from Crustacea. In A.H.L. Huiskes, W.W.C. Gieskes, J. Rozema, R.M.L. Schorno, S.M.van der Vies and W.J. Wolff (eds.), Proc. SCAR Biol. Symp. Amsterdam, Antarctic biology in a global context, pp. 201-214. Backhuys Publishers, Leiden.

Domack, E., D. Duran, A. Leventer, S. Ishman, S. Doane, S. McCallum, D. Amblas, J. Ring, R. Gilbert and M. Prentice. 2005. Stability of the Larsen B ice shelf on the Antarctic Peninsula during the Holocene epoch. Nature, 436: 681-685.

Dworschak, P.C. - 2000. Global diversity in the Thalassinidea (Decapoda). J. Crust. Biol., 20: 238-245.

Eastman, J.T. - 2000. Antarctic notothenioid fishes as subjects for research in evolutionary biology. Antarct. Sci, 12: 276-287.

Eastman, J.T. and A. Clarke. - 1998. A comparison of adaptive radiations of Antarctic fish with those of non-Antarctic fish. In: G. Di Prisco, E. Pisano and A. Clarke (eds.), Fishes of Antarctica: a Biological Overview, pp.3-26. Springer, Berlin.

Fernández, M., N. Ruiz-Tagle, S. Cifuentes, H.O. Pörtner and W. Arntz. - 2003. Oxygen-dependent asynchrony of embryonic development in embryo masses of brachyuran crabs. Mar. Biol., 142 (3): 559-565.

Frederich, M., F. J. Sartoris, W. Arntz and H.O. Pörtner. - 2000 Haemolymph $\mathrm{Mg}^{2+}$ regulation in decapod crustaceans: physiological correlates and eological consequences in polar areas. $J$. Exp. Biol., 203: 1383-1393

Frederich, M., F.J. Sartoris and H.O. Pörtner. - 2001. Distribution patterns of decapod crustaceans in polar areas: a result of magnesium regulation? Polar Biol., 24: 719-723.

Freire, A.S., T.M. Absher, A.C. Cruz-Kaled, K.L. Elbers and Y. Kern. - 2005. Abundance and distribution of invertebrate larvae in relation to environmental factors of near-shore waters of Admiralty Bay, King George Island, Antarctica. In: Abstracts of SCAR Internat. Biology Symp. ,Evolution and Biodiversity in Antarctica", Curitiba, Brazil: 233.

Gallardo, V.A. - 1987. The sublittoral macrofaunal benthos of the Antarctic shelf. Environm. Intern., 13: 71-81.

Gallardo, V.A. and J.G. Castillo. - 1969. Quantitative benthic survey of the infauna of Chile Bay (Greenwich I., South Shetland Is.). Gayana, 16: 3-18.

Gallardo, C. and P. Penchaszadeh. - 2001. Hatching mode and latitude in marine gastropods: revisiting Thorson's paradigm in the southern hemisphere. Mar. Biol., 138: 547-552.

Gambi, M.C., A. Castelli and M. Guizzardi. - 1997. Polychaete populations of the shallow soft bottoms off Terra Nova Bay (Ross Sea, Antarctica): distribution, diversity and biomass. Polar Biol., 17: 199-210.

Gambi, M.C. and S. Bussotti. - 1999. Composition, abundance and stratification of soft-bottom macrobenthos from selected areas of the Ross Sea shelf (Antarctica). Polar Biol., 21: 347-354.

Gambi, M.C., M.C. Buia, L. Mazzella, M. Lorenti and M.B. Scipione. -2000 . Spatio-temporal variability in the structure of benthic populations in a physically controlled system off Terra Nova Bay: the shallow hard bottoms. In: F.M. Faranda, L. Guglielmo and A. Ianora (eds.), Ross Sea Ecology, pp. $527-$ 538. Springer, Berlin.

Gambi, M.C., F.P. Patti, G. Micaletto and A. Giangrande. - 2001 Diversity of reproductive features in some Antarctic polynoid and sabellid polychaetes, with a description of Demonax polarsterni sp. n. (Polychaeta, Sabellidae). Polar Biol., 24: 883-891.

Gaston, K.J. and S.L. Chown. - 1999. Why Rapoport's rule does not generalise. Oikos, 84: 309-311.

Gatti, S. - 2001. Antarctic Sponges, In: J.A. Kaandorp and J.E. Kübler (eds.), The Virtual Laboratory: The Algorithmic Beauty of Seaweeds, Sponges, and Corals, pp. 160-162. Springer, Berlin.

Gerdes, D. and A. Montiel. - 1999. Distribution patterns of macrozoobenthos: a comparison between the Magellan Region and the Weddell Sea (Antarctic). Sci. Mar., 63(Suppl. 1): 149-154.

Gerdes, D., M. Klages, W.E. Arntz, R.L. Herman, J. Galéron and S. Hain. - 1992. Quantitative investigations on macrobenthos communities of the southeastern Weddell Sea shelf based on multibox corer samples. Polar Biol., 12: 291-301.

Gerdes, D., B. Hilbig and A. Montiel. - 2003. Impact of iceberg scouring on macrobenthic communities in the high Antarctic Weddell Sea. Polar Biol., 26: 295-301.

Gersonde, R., A. Abelmann, G. Cortese, S. Becquey, C. Bianchi, U. Brathauer, H.-S. Niebler, U. Zielinski and J. Pätzold. - 2003. The Late Pleistocene South Atlantic and Southern Ocean Surface - A summary of time-slice and time-series studies. In: G. Wefer, S. Mulitza and V. Rathmeyer (eds), The South Atlantic in the Late Quaternary: Reconstruction of Material Budgets and Current Systems, 499-529. Springer, Berlin.

Gili, J.-M., V. Alvà, F. Pagés, H. Klöser and W.E. Arntz. - 1996. Benthic diatoms as the major food source in the sub-Antarctic marine hydroid Silicularia rosea. Polar Biol., 16: 507-512.

Gili, J.-M., V. Alvà, R. Coma, C. Orejas, F. Pagès, M. Ribes, M. Zabala, W.E. Arntz, J. Bouillon, F. Boero and R. Hughes. 1998. The impact of small benthic passive suspension feeders in shallow marine ecosystems: the hydroids as an example. Zool. Verh. Rijksmus. Nat. Hist. Leiden, 323: 99-105.

Gili, J.M., R. Coma, C. Orejas, P.J. López-González and M. Zabala. - 2001. Are Antarctic suspension-feeding communities different from those elsewhere in the world? Polar Biol., 24: 473-485.

Glorioso, P.D., A.R. Piola and R.R. Leben. - 2005. Mesoscale eddies in the Subantarctic Front - Southwest Atlantic. In: W.E. Arntz, G.A. Lovrich and S. Thatje (eds.), The MagellanAntarctic connection: links and frontiers at high southern latitudes. Sci. Mar., 69 (Suppl. 2): 7-15.

Gómez, I., C. Wiencke and G. Weykam. - 1998. Life strategy of Antarctic macroalgae. Ber. Polarforsch., 299: 90-94.

Gorny, M. - 1999. On the biogeography and ecology of the Southern Ocean decapod fauna. Sci. Mar., 63 (Suppl. 1): 367-383.

Gorny, M., W.E. Arntz, A. Clarke and D.J. Gore. - 1992. Reproductive biology of caridean decapods from the Weddell Sea. Polar Biol., 12: 111-120.

Gorny, M., T. Brey, W.E. Arntz and T. Bruns. - 1993. Growth, development and productivity of Chorismus antarcticus (Pfeffer) (Crustacea: Decapoda: Natantia) in the eastern Weddell Sea, Antarctica. J. Exp. Mar. Biol. Ecol., 174: 261-275.

Gray, J.S. - 2001. Antarctic marine benthos biodiversity in a worldwide latitudinal context. Polar Biol., 24: 633-641.

Gutt, J. - 2001. On the direct impact of ice on the marine benthic communities, a review. Polar Biol., 24: 553-564.

Gutt, J. and D. Piepenburg. - 2003. Scale-dependent impact on diversity of Antarctic benthos caused by grounding of icebergs. Mar. Ecol. Progr. Ser., 253: 77-83.

Gutt, J. and A. Starmans. - 1998. Structure and biodiversity of megabenthos in the Weddell and Lazarev Seas (Antarctica): ecological role of physical parameters and biological interactions. Polar Biol., 20: 229-247.

Gutt, J. and A. Starmans. - 2001. Quantification of iceberg impact and benthic recolonisation patterns in the Weddell Sea (Antarctica), Polar Biol., 24: 615-619.

Gutt, J., A. Starmans and G. Dieckmann. - 1996. Impact of iceberg scouring on polar benthic habitats, Mar. Ecol. Progr. Ser., 137: 311-316.

Gutt, J., V. Storch and W.E. Arntz. - 1998. Benthosforschung im Südpolarmeer - Störung schafft Vielfalt, BIUZ, 28 (6): 362-370.

Gutt, J., E. Helsen, W.E. Arntz and A. Buschmann. - 1999. Biodiversity and community structure of the mega-epibenthos in the Magellan region (South America). Sci. Mar., 63(Suppl. 1): $155-170$

Gutt, J., W.E. Arntz, E. Balgerias, A. Brandt, D. Gerdes, M. Gorny and B. Sirenko. - 2003. Diverse approaches to questions of biodiversity: German contributions to studies of marine benthos around South America and Antarctica. Gayana, 67: 177-189.

Gutt, J., B.I. Sirenko, I.S. Smirnov and W.E. Arntz. - 2004. How many macrozoobenthic species might inhabit the Antarctic shelf? Antarct. Sci., 16: 11-16.

Hain, S. and P. Arnaud. - 1992. Notes on the reproduction of high Antarctic molluscs from the Weddell Sea. Polar Biol., 12: 303-312.

Hanelt, D. - 1996. Photoinhibition of photosynthesis in marine macroalgae (Review). Sci. Mar., 60(Suppl. 1): 243-248.

Heilmayer, O., T. Brey, M. Chiantore, R. Cattaneo-Vietti and W.E. Arntz. - 2003. Age and productivity of the Antarctic scallop, Adamussium colbecki, in Terra Nova Bay (Ross Sea, Antarctica). J. Exp. Mar. Biol. Ecol., 288: 239-356. 
Held, C. - 2000. Phylogeny and biogeography of serolid isopods (Crustacea, Isopoda, Serolidae) and the use of ribosomal expansion segments in molecular systematics. Mol. Phylogen. Evol., 15: $165-178$.

Held, C. - 2001. No evidence for slow-down of molecular substitution rates at subzero temperatures in Antarctic serolid isopods (Crustacea, Isopoda, Serolidae). Polar Biol., 24: 497-501.

Held, C. -2003 . Molecular evidence for cryptic speciation within the widespread Antarctic crustacean Ceratoserolis trilobitoides (Crustacea, Isopoda). In: A.H.L. Huiskes, W.W.C. Gieskes, J. Rozema, R.M.L. Schorno, S.M. van der Vies and W.J. Wolff (eds.), Proc. SCAR Biol. Symp. Amsterdam, Antarctic biology in a global context, pp. 135-139. Backhuys Publishers, Leiden.

Held, C. and J.-W. Wägele. - 2005. Cryptic speciation in the giant Antarctic isopod Glyptonotus antarcticus (Isopoda, Valvifera, Chaetiliidae). In: W.E. Arntz, G.A. Lovrich and S. Thatje (eds.), The Magellan-Antarctic connection: links and frontiers at high southern latitudes. Sci. Mar., 69 (Suppl. 2): 175-181.

Helmuth, B., R.R. Veit and R. Holberton. - 1994. Long-distance dispersal of a Subantarctic brooding bivalve (Gaimardia trapesina) by kelp-rafting. Mar. Biol., 120: 421-426.

Hernández, C.E., R.A. Moreno and N. Rozbaczylo. - 2005. Biogeographical patterns and Rapoport's rule in southeastern Pacific benthic polychaetes of the Chilean coast. Ecography, 28: 363-373.

Hernando, M., J.I. Carreto, M.O. Carrignan, G.A. Ferreyra and C. Gross. - 2001. Effects of solar radiation on growth and mycosporine-like amino acids content in Thalassiosira sp., an Antarctic diatom. Polar Biol., 25: 12-20.

Hill, M.O. - 1973. Diversity and evenness: A unifying notation and its consequences. Ecology, 54: 427-431.

Iken, K. - 1996. Trophische Beziehungen zwischen Makroalgen und Herbivoren in der Potter Cove (King-George-Insel, Antarktis). Ber. Polarforsch., 201: 206 pp.

Iken, K., M.L. Quartino, E. Barrera-Oro, J. Palermo, C. Wiencke and T. Brey. - 1998. Trophic relations between macroalgae and herbivores, Ber. Polarforsch., 299: 258-262.

Jablonski, D., K. Roy and J.W. Valentine. - 2003. Evolutionary macroecology and the fossil record. In: T. Blackburn and K.J. Gaston (eds.), Macroecology: Concepts and Consequences, pp. 368-390. Blackwell Scientific, Oxford.

Jazdzewski, K., C. De Broyer, M. Pudlarz and D. Zielinski. - 2001. Seasonal fluctuations of vagile benthos in the uppermost sublittoral of a maritime Antarctic fjord. Polar Biol., 24: 910-917.

Kim, D. - 2001. Seasonality of marine algae and grazers of an Antarctic rocky intertidal, with emphasis on the role of the limpet Nacella concinna Strebel (Gastropoda: Patellidae). Ber. Polarforsch., 397: 1-120.

Klöser, H., M.L. Quartino and C. Wiencke. - 1996. Distribution of macroalgae and macroalgal communities in gradients of physical conditions in Potter Cove, King George Island, Antarctica. Hydrobiologia, 333: 1-17.

Knust R., W.E. Arntz, M. Boche, T. Brey, D. Gerdes, K. Mintenbeck, A. Schröder, A. Starmans and N. Teixidó. - 2003. Iceberg scouring on the eastern Weddell Sea shelf (Antarctica): a benthic system shaped by physical disturbances? In: A.H.L. Huiskes, W.W.C. Gieskes, J. Rozema, R.M.L. Schorno, S.M. van der Vies and W.J. Wolff (eds.), Proc. SCAR Biol. Symp. Amsterdam, Antarctic biology in a global context, pp. 96-101. Backhuys Publishers, Leiden.

Kowalke, J. and D. Abele. - 1998. A first record of the soft bottom infauna community of Potter Cove. Ber. Polarforsch., 299: 106-112.

Kowalke, J., M. Tatián, R. Sahade and W.E. Arntz. - 2001. Production and respiration of Antarctic ascidians. Polar Biol., 24: 663-669.

Lamy, F., D. Hebbeln and G. Wefer. - 1999. High-resolution marine record of climatic change in mid-latitude Chile during the last 28,000 years based on terrigenous sediment parameters. Quaternary Res., 51: 83-93.

Lamy, F., D. Hebbeln, U. Röhl and G. Wefer. - 2001. Holocene rainfall variability in southern Chile: a marine record of latitudinal shifts of the Southern Westerlies. Earth and Planet. Sci Letters, 185: 369-382.

Lamy, F., C. Rühlemann, D. Hebbeln and G. Wefer. - 2002. Highand low-latitude climate control on the position of the southern Peru-Chile Current during the Holocene. Paleoceanography,
17, No. 2, 1028: 16-1 - 16-10.

Lamy, F. J. Kaiser, U. Ninnemann, D. Hebbeln, H.W. Arz and J. Stoner. - 2004. Antarctic timing of surface water changes off Chile and Patagonian Ice Sheet response. Science, 304: 19591962.

Lavaleye, M., S. Thatje, G. Duineveld and W.E. Arntz. - 2005. Pelagic larvae and juveniles of benthic invertebrates in the near-bottom environment. Ber. Polarforsch. Meeresforsch. 503: $31-35$

Lee, H.J., D. Gerdes, S. Vanhove and M. Vincx. - 2001a. Meiofauna response to iceberg disturbance on the Antarctic continental shelf at Kapp Norwegia (Weddell Sea). Polar Biol., 24: 926-933.

Lee, H.J., S. Vanhove, L.S. Peck and M. Vincx. - 2001b. Recolonisation of meiofauna after catastrophic iceberg scouring in shallow Antarctic sediments. Polar Biol., 24: 918-925.

Lee, Y.-H., M. Song, S. Lee, R. León, S.O. Godoy and I. Cañete. 2004. Molecular phylogeny and divergence time of the Antarctic sea urchin (Sterechinus neumayeri) in relation to the South American sea urchins. Antarct. Sci, 16: 29-36.

Lenihan, H.S. and J.S. Oliver. - 1995. Anthropogenic and natural disturbances to marine benthic communities in Antarctica. Ecol. Appl., 5: 311-326.

Linse, K. - 2002. The Shelled Magellanic Mollusca: With Special Reference to Biogeographic Relations in the Southern Ocean. A.R.G. Gantner Verlag, Rugell.

Linse, K. - 2004. Scotia Arc deep-water bivalves: composition, distribution and relationship to the Antarctic shelf fauna. Deep-Sea Res. II, 51: 1827-1837.

Lörz, A.-N. and A. Brandt. - 2004. Phylogeny of Antarctic Epimeria (Epimeriidae, Amphipoda). J. Mar. Biol. Assoc. UK, 84: 179-190.

Lörz, A.-N. and C. Held. - 2004. A preliminary molecular and morphological phylogeny of the Antarctic Epimeriidae and Iphimediidae (Crustacea, Amphipoda). Mol. Phylogenet. Evol., 31: 4-15.

Longhi, M.L., I.R. Schloss and C. Wiencke. - 2003. Effect of irradiance and temperature on photosynthesis and growth of two Antarctic benthic diatoms, Gyrosigma subsalinum and Odontella litigiosa. Bot. Mar., 46: 276-284.

Lovell, L.L. and Trego, K.D. - 2003. The epibenthic megafaunal and benthic infaunal invertebrates of Port Foster, Deception Island (South Shetland Islands, Antarctica). Deep-Sea Res. II, 50: 1799-1819.

Lovrich, G.A. - 1997. La pesquería mixta de las centollas Lithodes santolla y Paralomis granulosa (Anomura: Lithodidae) en Tierra del Fuego, Argentina. Invest. Mar., Valparaíso, 25: 41-57.

Lovrich, G.A. and J.H. Vinuesa. - 1996. Reproductive strategies of two lithodids in the Beagle Channel, Argentina: a complementary management tool in a changing fishery. In: Baxter, B. (ed.), High Latitude Crabs: Biology, Management, and Economics, pp. 333-340. Univ. Alaska, Fairbanks.

Lovrich, G.A., M.C. Romero, F. Tapella and S. Thatje. - 2005. Distribution, reproductive and energetic conditions of decapod crustaceans along the Scotia Arc (Southern Ocean). In: W.E. Arntz, G.A. Lovrich and S. Thatje (eds.), The MagellanAntarctic connection: links and frontiers at high southern latitudes. Sci. Mar., 69(Suppl. 2): 65-89.

Lüder, U., J. Knötzel and C. Wiencke. - 2001. Acclimation of photosynthesis and pigments to seasonally changing light conditions in the endemic Antarctic red macroalga Palmaria decipiens. Polar Biol., 24: 598-603.

Mackensen, A. - 2004. Changing Southern Ocean palaeocirculation and effects on global climate. Antarct. Sci, 16: 369-386.

Malumian, N. and E. Olivero. - 2005. Shallow-water late middle Eocene crinoids from Tierra del Fuego: a new southern record of a retrograde community structure. In: W.E. Arntz, G.A. Lovrich and S. Thatje (eds.), The Magellan-Antarctic connection: links and frontiers at high southern latitudes. Sci. Mar., 69 (Suppl. 2): 349-353.

McCulloch, R. and S. Davies. - 2001. Late-glacial and Holocene palaeoenvironmental change in the central Strait of Magellan, southern Patagonia. Palaeogeogr. Palaeocl., 173: 143-173.

Mercuri, G., K. Iken, B. Ledesma and R.F. Dubois. - 1998. On the distribution patterns and density of the Antarctic infaunal bivalve Laternula elliptica in Potter Cove, King George Island, Antarctica. Ber. Polarforsch., 299: 137-143. 
Mintenbeck, K. - 2001. Das Nahrungsnetz der demersalen Fischfauna in ungestörten und gestörten Gebieten auf dem Kontinentalschelf des östlichen Weddellmeeres. Diploma thesis, Univ. Bremen.

Momo, F., E. Bogazzi and F. Duttweiler. - 1998. Amphipods of Potter Cove: community composition, biology and growth. Ber. Polarforsch., 299: 144-149.

Montiel, A., D. Gerdes and C. Ríos. - 2001. Distribución y abundancia del macrozoobentos en una microcuenca marina submareal del Estrechio de Magallanes, Chile. Ans. Inst. Pat., Ser. Cs. Nat., 29: 117-133.

Montiel, A., C. Ríos, E. Mutschke and N. Rozbaczylo. - 2004. Poliquetos de fiordos y canales adyacentes al campo de hielo patagónico sur, Chile (Annelida: Polychaeta). Cienc. Tecnol. Mar, 27 (1): 49-67.

Montiel, A., D. Gerdes, B. Hilbig and W.E. Arntz. - 2005. Polychaetes on the Magellan and Weddell Sea shelves: a comparative ecological evaluation. Mar. Ecol. Prog. Ser., 297: 189-202.

Morales-Nin, B., J. Moranta and E. Balguerías. - 2000. Growth and age validation in high-Antarctic fish. Polar Biol., 23: 626-634.

Mutschke, E., C. Ríos and A. Montiel. - 1998. Situación actual de la macrofauna presente en el intermareal de bloques y cantos de Bahía Laredo, Estrecho de Magallanes. Ans. Inst. Pat., Ser. Cs. Nat., 26: 5-29.

Mutschke, E., C. Ríos, T. Hromic, M. Gorny, A. Montiel, M. Rauschert and D. Gerdes. - 1996. Estudios bentónicos en fior-

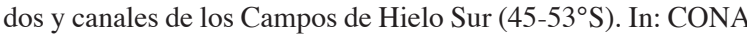
(ed.), Resultados Crucero CIMAR-FIORDO 2: 91-98.

Nyssen, F., T. Brey, G. Lepoint, J.-M. Bouquegneau, C. De Broyer and P. Dauby. - 2002. A stable isotope approach to the eastern Weddell Sea trophic web: focus on benthic amphipods. Polar Biol., 25: 280-287.

Obermüller, B., U. Karsten, H.O. Pörtner and D. Abele. - 2003. Effects of UV-radiation on oxidative stress parameters in polar marine amphipods, and the role of UV-absorbing mycosporinelike amino acids (MAAs) in their diet. In: A.H.L. Huiskes, W.W.C. Gieskes, J. Rozema, R.M.L.. Schorno, S.M. van der Vies, and W.J. Wolff (eds.), Antarctic biology in a global context, pp. 63-68. Backhuys Publishers, Leiden.

Olaso, I., M. Rauschert and C. De Broyer. - 2000. Trophic ecology of the family Artedraconidae (Pisces, Osteichthyes) and its impact on the eastern Weddell sea benthic system. Mar. Ecol. Prog. Ser. 194: 143-158.

Orejas, C., J.M. Gili, W.E. Arntz, J.D. Ros, P. López, N. Teixidó and P. Filipe. -2000 . Benthic suspension feeders, key players in Antarctic marine ecosystems? Contr. to Sci. 1: 299-311.

Orejas, C., J.M. Gili, P.J. López-González and W.E. Arntz. - 2001 Feeding strategies and diet composition of four Antarctic cnidarian species. Polar Biol., 24: 620-627.

Orejas, C., P. López, J.M. Gili, N. Teixidó, J. Gutt and W. Arntz. 2002. Distribution and reproductive ecology of the Antarctic octocoral Ainigmaptilon antarcticum in the Weddell Sea. Mar. Ecol. Progr. Ser., 231: 101-114.

Orejas C., J.M. Gili and W. Arntz. - 2003. Role of small-plankton communities in the diet of two Antarctic octocorals (Primnoisis antarctica and Primnoella sp.). Mar. Ecol. Progr. Ser., 250: 105-116.

Page, T. and K. Linse. - 2002. More evidence of speciation and dispersal across the Antarctic Polar Front through molecular systematics of Southern Ocean Limatula (Bivalvia: Limidae). Polar Biol., 25: 818-826.

Parapar, J. and G. San Martín. - 1997. "Sedentary" polychaetes of the Livingston Island shelf (South Shetlands, Antarctica), with the description of a new species. Polar Biol., 17: 502-514.

Pearse, J.S., J.B. McClintock and I. Bosch. - 1991. Reproduction of Antarctic marine invertebrates: tempos, modes and timing. Am. Zool., 31: 65-80.

Pearse, J.S. - 1994. Coldwater-echinoderms break Thorson's rule. In: C.M. Young and K.J. Eckelbarger (eds.), Reproduction, Larval Biology, and Recruitment of the Deep-Sea Benthos, pp. 26-39. Columbia Univ. Press, New York.

Peck, L.S. - 2001. Ecophysiology of Antarctic marine ectotherms: limits to life. Polar Biol., 25: 31-40.

Piepenburg, D., M.K. Schmid and D. Gerdes. - 2002. The benthos off King George Island (South Shetland Islands, Antarctica) further evidence for a lack of a latitudinal biomass cline in the Southern Ocean. Polar Biol., 25: 146-158.

Pimm S.L., J.H. Lawton and J.E. Cohen. - 1991. Food web patterns and their consequences. Nature, 350: 669-674.

Pisano, E. and C. Ozouf-Costaz. - 2000. Chromosome change and the evolution in the Antarctic fish suborder Notothenioidei. Antarct. Sci., 12: 334-342.

Pörtner, H.O., D. Storch and O. Heilmayer. - 2005. Constraints and trade-offs in climate-dependent adaptation: energy budgets and growth in a latitudinal cline. In: W.E. Arntz, G.A. Lovrich and $\mathrm{S}$. Thatje (eds.), The Magellan-Antarctic connection: links and frontiers at high southern latitudes. Sci. Mar., 69(Suppl. 2): 271-285.

Poulin, E., A.T. Palma and Jean-Pierre Féral. - 2002. Evolutionary versus ecological success in Antarctic benthic invertebrates. Trends Ecol. Evol., 17: 218-222.

Povero, P., M. Chiantore, C. Misic, G. Budillon and R. CattaneoVietti. - 2001. Land forcing controls pelagic-benthic coupling in Adelie Cove (Terra Nova Bay, Ross Sea). Polar Biol., 24: 875-882.

Quartino, M.L., H. Klöser, A. Boraso de Zaixso and H. Zaixso. 1998. Communities of benthic marine algae at a sheltered site in Potter Cove, King George Island, South Shetlands, Antarctica. Ber. Polarforsch., 299: 74-81.

Raguá-Gil, J.M., J. Gutt and W.E. Arntz. - 2004. Antarctic shallowwater mega-epibenthos: shaped by circumpolar dispersion or local conditions? Mar. Biol., 144: 829-839.

Ramos, A. - 1999. The megazoobenthos of the Scotia Arc islands. Sci. Mar., 63 (Suppl. 1): 171-182.

Rignot, E., A. Rivera and G. Cassassa. - 2003. Contribution of the Patagonia Icefields of South America to sea level rise. Science, 302: 434-437

Ríos, C. and E. Mutschke. - 1999. Community structure of intertidal boulder-cobble fields in the Strait of Magellan, Chile. Sci. Mar., 63, Suppl. 1: 193-201.

Ríos, C., E. Mutschke and E. Morrison. - 2003. Biodiversidad bentónica sublitoral en el Estrecho de Magallanes, Chile. Rev. Biol. Mar. Oceanogr., 38: 1-12.

Romero, M.C., F. Tapella, G.A. Lovrich and S. Thatje. - 2003 a. Reproductive modes and distribution of benthic crustaceans along the Scotia Arc. Ber. Polar Meeresforsch., 462: 67-72.

Romero, M.C., F. Vanella, F. Tapella and G.A. Lovrich. - 2003b. Oxygen consumption associated with feeding habits of Munida subrugosa (Crustacea, Decapoda) in the Beagle Channel. In: S. Thatje, J.A. Calcagno and W.E. Arntz, Extended Abstracts of the IBMANT/ANDEEP International Symposium and Workshop, Ushuaia: 177f.

Roy, K., D. Jablonski and J.W. Valentine. - 2000. Dissecting latitudinal diversity gradients: functional groups and clades of marine bivalves. P. Roy. Soc. Lond. B, 267: 293-299.

Sahade, R., M. Tatián, F. Mattio and G. Esnal. - 1998. Seasonality in reproduction of Antarctic ascidians (Molgula pedunculata, Cnemidocarpa verrucosa and Pyura setosa). Ber. Polarforsch., 299: 123-229.

Sáiz-Salinas, J.I., A. Ramos, F.J. Garcia, J.S. Troncoso, G. San Martín, C. Sanz and C. Palacin. - 1997. Quantitative analysis of macrobenthic soft-bottom assemblages in South Shetland waters (Antarctica). Polar Biol., 17: 393-400.

San Martín, G. and J. Parapar. - 1997. "Errant" polychaetes of the Livingston Island shelf (South Shetlands, Antarctica), with the description of a new species. Polar Biol., 17: 285-295.

Santelices, B. - 1989. Algas Marinas de Chile. Distribución, Ecología, Utilización, Diversidad. Edic. Univ. Católica Chile, Santiago.

Schnack-Schiel, S. and E. Isla. - 2005. The role of zooplankton in the pelagic-benthic coupling. In: W.E. Arntz, G.A. Lovrich and S. Thatje (eds.), The Magellan-Antarctic connection: links and frontiers at high southern latitudes. Sci. Mar., 69(Suppl. 2): 39-55.

Schmidt, A. and A. Brandt. - 2001. The tanaidacean fauna of the Beagle Channel (southern Chile) and its relationship to the fauna of the Antarctic continental shelf. Antarct. Sci., 13: 420-429.

Schrödl, M. - 2003. Sea Slugs of Southern South America. Systematics, Biogeography and Biology of Chilean and Magellanic Nudipleura (Mollusca: Opisthobranchia). ConchBooks, Hackenheim.

SERNAP (Servicio Nacional de Pesca, Chile). - 2005. See http://www.sernapesca.cl

Shevenell, A.E., J.P. Kennett and D.W. Lea. - 2004. Middle Miocene Southern Ocean cooling and Antarctic cryosphere expansion. Science, 305: 1766-1770. 
Sieg, J. - 1992. On the origin and age of the Antarctic tanaidacean fauna. In: V.A. Gallardo, O. Ferretti and H. Moyano (eds.), Oceanografía en Antártica, pp. 421-429. Centro EULA - Univ. Concepción.

Sirenko, B.I. - 2000. Symbiosis of an Antarctic gastropod and pantopod. Ruthenica, 10: 159-162.

Sirenko, B., I. Smirnov and W.E. Arntz. - 1997. Taxonomic biodiversity of bottom invertebrates in the eastern Weddell Sea. In: W.E. Arntz and J. Gutt (eds.), The Expedition Antarktis XIII/3 (EASIZ I) of „Polarstern“ to the eastern Weddell Sea in 1996. Ber. Polarforsch., 249: 25-31.

Sirenko, B., I. Smirnov and W.E. Arntz. - 2001. Biodiversity of macrozoobenthic communities in the eastern Weddell Sea and at the Antarctic Peninsula. In: W.E. Arntz and T. Brey (eds.), The Expedition Antarktis XVII/3 (EASIZ III) of RV „Polarstern“ in 2000. Ber. Polarforsch. Meeresforsch., 402: 113-116.

Stanwell-Smith, D. and Peck, L.S. - 1998. Temperature and embryonic development in relation to spawning and field occurrence of larvae of three Antarctic echinoderms. Biol. Bull., 194: 44-52.

Stanwell-Smith, D., L.S. Peck, A. Clarke, A.W.A. Murray and C. Todd. - 1999. The distribution, abundance and seasonality of pelagic marine invertebrate larvae in the maritime Antarctic. Phil. Trans. Roy. Soc. Lond. B, 354: 471-484.

Stark, J. S. and M.J. Riddle. - 2003. Human impacts in marine benthic communities at Casey Station: description, determination and demonstration of impacts. In: A.H.L. Huiskes, W.W.C. Gieskes, J. Rozema, R.M.L. Schorno, R.M.L., S.M. van der Viesand W.J. Wolff (eds.), Antarctic biology in a global context, pp. 278-284. Backhuys Publishers, Leiden.

Starmans, A. and J. Gutt. - 2002. - Mega-epibenthic diversity: a polar comparison. Mar. Ecol. Progr. Ser., 225: 45-52.

Starmans, A., J. Gutt and W.E. Arntz. - 1999. Mega-epibenthic communities in Arctic and Antarctic shelf areas. Mar. Biol., 135: 269-280

Storch, D., B.A. Bluhm and W.E. Arntz. - 2001. Microscopic anatomy and ultrastructure of the digestive system of three Antarctic shrimps (Crustacea: Decapoda: Caridea). Polar Biol., 24: 604-614.

Tapella, F., G. Lovrich, M.C. Romero and S. Thatje. - 2002. Reproductive biology of the crab Munida subrugosa (Decapoda: Anomura: Galatheidae) in the Beagle Channel, Argentina. $J$. Mar. Biol. Ass. UK, 82: 589-595.

Tatián, M., R. Sahade, M.E. Doucet and G. B. Esnal. - 1998. Some aspects on Antarctic ascidians (Tunicata, Ascidiacea) of Potter Cove, King George Island. Ber. Polarforsch., 299: 113-118.

Tavares, M. and G.A.S. Melo. - 2004. Discovery of the first known benthic invasive species in the Southern Ocean: the North Atlantic spider crab Hyas araneus found in the Antarctic Peninsula. Antarct. Sci., 16: 129-131.

Taviani, M., A. Beu and C. Lombardo. - 1998. Pleistocene macrofossils from CRP-1 drillhole, Victoria Land basin, Antarctica. Terra Antarctica, 5: 485-491.

Teixidó, N., J. Garrabou and W. Arntz. - 2002. Spatial pattern quantification of Antarctic benthic communities using Landscape indices. Mar. Ecol. Progr. Ser., 242: 1-14.

Teixidó, N., J. Garrabou, J. Gutt and W.E. Arntz. - 2004. Recovery in Antarctic benthos after iceberg disturbance: trends in benthic composition, abundance, and growth forms. Mar. Ecol. Progr. Ser., 278: 1-16.

Teixidó, N., J.-M. Gili, M.J. Uriz, J. Gutt and W.E. Arntz. - (in press). Observations of asexual strategies in hexactinellid sponges from ROV video records. Deep-Sea Res. II

Thatje, S. -2000 . Notiax santarita, a new species of the Callianassidae (Decapoda, Thalassinidea) from the Beagle Channel, southernmost America. Crustaceana ,73: 289-299.

Thatje, S. and W.E. Arntz. - 2004. Antarctic reptant decapods: Thatje, S. and W.E. Arntz (eds.). - in press. Macrobenthic studies at Bouvet Island. Special Issue. Polar Biol.

Thatje, S. and V. Fuentes. - 2003. First record of anomuran and brachyuran larvae (Crustacea: Decapoda) from Antarctic waters. Polar Biol., 26: 279-282.

Thatje, S. and D. Gerdes. - 2000. Upogebia australis, a new species of the Upogebiidae (Crustacea, Decapoda, Thalassinidea) from the Beagle Channel (Magellan region). Mitt. Mus. Naturkde Berlin, Zool. Reihe, 76: 231-236.
Thatje, S. and A.-N. Lörz. - 2005. First record of lithodid crabs from Antarctic waters off the Balleny Islands. Polar Biol., 28: 334-337.

Thatje, S. and G.A. Lovrich. - 2003. Decapodid and early juvenile development in the protandrous shrimp Campylonotus vagans (Crustacea: Decapoda: Caridea), with notes on larval morphology. J. Mar. Biol. Ass. UK, 83: 103-109.

Thatje, S. and E. Mutschke. - 1999. Distribution of abundance, biomass, production and productivity of macrobenthos in the Subantarctic Magellan Province (South America). Polar Biol., 22 31-37.

Thatje, S., S. Schnack-Schiel and W. Arntz. - 2003. Developmental trade-offs in Subantarctic meroplankton communities and the enigma of low decapod diversity in high southern latitudes. Mar. Ecol. Prog. Ser., 260: 195-207.

Thatje, S., G.A. Lovrich, G. Torres, W. Hagen and K. Anger. 2004. Changes in biomass, lipid, fatty acid and elemental composition during abbreviated larval development of the Subantarctic shrimp Campylonotus vagans. J. Exp. Mar. Biol. Ecol., 301: 159-174.

Thatje, S., K. Anger, J.A. Calcagno, G.A. Lovrich, H.O. Pörtner and W.E. Arntz. - 2005a. Challenging the cold: crabs re-conquer the Antarctic. Ecology, 86: 619-625.

Thatje, S., C.-D. Hillenbrand and R. Larter. - 2005b. On the origin of Antarctic marine benthic community structure. Trends Ecol. Evol., 20: 534-540.

Thatje, S., R. Bacardit and W.E. Arntz. - 2005c. Larvae of the deepsea Nematocarcinidae (Crustacea: Decapoda: Caridea) from the Southern Ocean. Polar Biol., 28: 290-302.

Thiel, M. and L. Gutow. - 2004. The ecology of rafting in the marine environment. I. The floating substrata. Oceanogr. Mar. Biol. Ann. Rev., 42: 181-264.

Thomson, M.R.A. - 2005. Thoughts on controls on evolution and dispersal of benthos in the Magellan-Scotia Arc region: a workshop proposal. In: W.E. Arntz, G.A. Lovrich and S. Thatje (eds.), The Magellan-Antarctic connection: links and frontiers at high southern latitudes. Sci. Mar., 69(Suppl. 2): 355-358.

Ugland, K.I., J.S. Gray and K.E. Ellingsen. - 2003. The speciesaccumulation curve and estimation of species richness. J. Anim. Ecol., 72: 888-897.

Urban, H.J. - 1998. Upper temperature tolerance of two Antarctic molluscs (Laternula elliptica and Nacella concinna) from Potter Cove, King George Island, Antarctic Peninsula. Ber. Polarforsch., 299: 230-236.

Vacchi, M., M. La Mesa and S. Greco. - 2000. The coastal fish fauna of Terra Nova Bay, Ross Sea, Antarctica. In: F.M. Faranda, L. Guglielmo and A. Ianora (eds.), Ross Sea Ecology, pp. 457-468. Springer, Berlin.

Valdovinos, C., S.A. Navarrete and P.A. Marquet. - 2003. Mollusk species diversity in the southeastern Pacific: why are there more species towards the pole? Ecography, 26: 139-144.

Vaughan, D.G. and J.R. Spouge, 2002. Risk estimation of collapse of the West Antarctic Ice Sheet. Climate Change, 52: 65-91.

Vaughan, D.G., G.J. Marshall, W.M. Connolley, C. Parkinson, R. Mulvaney, D.A. Hodgson, J.C. King, C.J. Pudsey and J. Turner. - 2003. Recent rapid regional climate warming on the Antarctic Peninsula. Climate Change, 60: 243-274.

Vermeij, G.J. - 1991. Anatomy of an invasion: the trans-Arctic interchange. Paleobiol., 17: 281-307.

Voigt, M. - 2004. Wachstumsschwankungen der antarktischen Muschel Laternula elliptica in den letzten vierzig Jahren im Gebiet von King George Island. Dipl. thesis, Univ. Rostock.

Wägele, J.-W. - 1986. Polymorphism and distribution of Ceratoserolis trilobitoides (Eights, 1833) (Crustacea, Isopoda) in the Weddell Sea and synonymy with C. cornuta (Studer, 1879). Polar Biol., 6: 127-137.

Weykam, G., D. N. Thomas and C. Wiencke. -1997. Growth and photosynthesis of the Antarctic red algae Palmaria decipiens (Palmariales) and Iridaea cordata (Gigartinales) during and following extended periods of darkness. Phycologia, 36: 395-405.

White, W.B. and R.G. Peterson. - 1996. An Antarctic circumpolar wave in surface pressure, temperature and sea-ice extent Nature, 380: 699-702.

Wiencke, C. - 1990a. Seasonality of brown macroalgae from Antarctica - a long-term culture study under fluctuating Antarctic daylengths. Polar Biol., 10: 589-600. 
Wiencke, C. - 1990b. Seasonality of red and green macroalgae from Antarctica - a long-term culture study under fluctuating Antarctic daylengths. Polar Biol., 10: 601-607.

Wiencke, C. - 1996. Recent advances in the investigation of Antarctic macroalgae. Polar Biol., 16: 231-240.

Wiencke, C. and M.N. Clayton. - 2002. Antarctic Seaweeds. Synopses of the Antarctic Benthos 9, pp. 239. A.R.G. Gantner-Verlag, Rugell.

Wiencke, C. and I. tom Dieck. - 1989. Temperature requirements for growth and temperature tolerance of macroalgae endemic to the Antarctic region. Mar. Ecol. Progr. Ser., 54: 189-197.

Wiencke, C. and I. tom Dieck. - 1990. Temperature requirements for growth and survival of macroalgae from Antarctica and Southern Chile. Mar. Ecol. Progr. Ser., 59: 157-170.

Wiencke, C., M. Clayton and A. Peters. - 1998. Biodiversity, life cycles and evolution of Antarctic macroalgae. Ber. Polar- forsch., 299: 82-89.

Winkler, H. - 1994. Charakterisierung der Isopodenfauna (Crustacea, Malacostraca) des Scotia-Bogens aus biogeographischer Sicht: ein multivariater Ansatz. Ber. Polarforsch., 139: 196 pp.

Wright, J.D., K.G Miller and R.G. Fairbanks. - 1992. Early and middle Miocene stable isotopes: implications for deepwater circulation and climate. Paleoceanogr., 7: 357-389.

Zabala, M., C. Orejas and V. Alvà. - 1997. Bryozoans of the Weddell Sea. Ber. Polarforsch., 249: 55-61, 129-142.

Zachos, J.C., N.J. Shackleton, J.S. Revenaugh, H. Pälike and B.P. Flower. - 2001a. Climate response to orbital forcing across the Oligocene-Miocene boundary. Science, 292: 274-278.

Zachos, J.C., M. Pagani, L. Sloan, E. Thomas and K. Billups. 2001b. Trends, rhythms, and aberrations in global climate 65 Ma to present. Science, 292: 686-693. 
